\title{
Effects of additives on the non-premixed ignition of ethylene in air
}

\author{
Fokion N. EgOLFOPOULOS \\ Aerospace \& Mechanical Engineering Department \\ University of Southern California \\ Los Angeles, CA 90089-1453 \\ and \\ Paul E. Dimotakis \\ Graduate Aeronautical Laboratories \\ California Institute of Technology \\ Pasadena, CA 91125
}

The ignition characteristics of heated $\mathrm{C}_{2} \mathrm{H}_{4}$ counterflowing against heated air were numerically investigated in the presence of additives such as $\mathrm{NO}, \mathrm{F}_{2}$, and $\mathrm{H}_{2}$. $\mathrm{C}_{2} \mathrm{H}_{4}$ and air temperatures were chosen to resemble conditions relevant to highMach number, air-breathing propulsion. The numerical simulations were conducted along the stagnation streamline of the counterflow and included detailed descriptions of chemical kinetics and molecular transport. It was found that addition of NO at concentrations of about $10,000 \mathrm{ppm}(1 \%)$, results in a substantial increase of the ignition strain rate, from $300 / \mathrm{s}$ to values up to $32,000 / \mathrm{s}$. This ignition promotion is caused by enhanced radical production that is initiated through the interaction between $\mathrm{NO}$ and $\mathrm{HO}_{2}$. A further increase in the $\mathrm{NO}$ amount leads to reduced improvements. Small additions of $\mathrm{F}_{2}$ and $\mathrm{H}_{2}$ were also found to promote ignition, but to lesser extent compared to NO. Results also show that with the addition of $\mathrm{F}_{2}$ in the presence of $\mathrm{NO}$, ignition promotion is further enhanced, and for $\mathrm{F}_{2}$ and NO concentrations larger than 25,000 ppm, the system becomes hypergolic. The present investigations suggest that the use of $\mathrm{C}_{2} \mathrm{H}_{4}, \mathrm{NO}$, and $\mathrm{F}_{2}$ may permit ignition at conditions of relevance to SCRAMJET's. 


\section{Introduction}

The use of hydrocarbons for high Mach number, air-breathing propulsion was recently addressed (e.g., Edwards 1996). The concept pertains to flight Mach numbers and (static) temperatures in the range,

$$
4 \lesssim M_{\infty}<8, \quad 250 \mathrm{~K}<T_{\infty}<300 \mathrm{~K}
$$

where, for a perfect gas, we may expect temperatures of,

$$
T_{0}=\left[1+r\left(\frac{\gamma-1}{2}\right) M_{\infty}^{2}\right] T_{\infty}
$$

In this expression, $\gamma \equiv c_{p} / c_{v}$ the ratio of specific heats (here assumed constant) and $r$ a temperature-recovery factor. The latter ranges from unity for stagnation flow, to $\sim \operatorname{Pr}^{1 / 3}$ for turbulent boundary-layer wall recovery $(\operatorname{Pr} \simeq 0.7$, for air, is the Prandtl number), to $\sim \operatorname{Pr}^{1 / 2}$ for laminar boundary-layer wall recovery. Such temperatures may be expected for (near-)adiabatic conditions, but could be lowered by heat transfer and active cooling. For expected $M_{\infty}$ and $T_{\infty}$ conditions (Eq.1), we then expect,

$$
1000 \mathrm{~K} \lesssim T_{0} \lesssim 4000 \mathrm{~K}
$$

necessitating the use of endothermic fuels to cool the fuselage and internal-flow passages for flights of any duration (Egolfopoulos \& Dimotakis 1998, hereafter referred to as 'ED98').

The lower limit of the envisaged $M_{\infty}$ range is set by the ignition and flame stability characteristics of hydrocarbons, while the upper limit is set by the cooling ability of such fuels. Whether the proposed concept is realizable, depends critically on the ability to achieve and sustain ignition in a flow environment characterized by very high strain rates, imposed by large velocity gradients across air-fuel mixing layers. In this environment, strain rates of the order of $10^{4}-10^{6} / \mathrm{s}$ are expected (e.g., Egolfopoulos et al. 1996). Non-premixed hydrocarbons do not ignite nor sustain vigorous burning under such conditions (e.g., Fotache et al. 1997a, 1997b; Egolfopoulos et al. 1997). 
In the proposed hydrocarbon-fueled SCRAMJET concept, heat added to typical jet fuels in the course of endothermic cooling will result in fuel temperatures that will cause thermal cracking. At the expected sustained elevated fuel temperatures, the extent of cracking may be such that near-equilibrium compositions are attained. Thus, products of full, or partial, cracking will be fed into the combustor. As a result, ignition behavior will be that of a fuel blend of lower molecular weight constituents. While the elevated temperatures of such fuel blends will promote ignition, it is not clear whether that alone is sufficient and what the combined effect of the various components will be.

The ED98 numerical study focused on the non-premixed ignition of fuel blends that may result from the thermal cracking of $\mathrm{C}_{12} \mathrm{H}_{26}$, a representative constituent of kerosene-type fuels. For fuel temperatures in the range, $800 \mathrm{~K}<T_{\text {fuel }}<1050 \mathrm{~K}$ ( $c f$. Eq. 2), equilibrium calculations revealed that the fuel blend composition is largely controlled by nearly-equal amounts of $\mathrm{CH}_{4}$ and $\mathrm{C}_{2} \mathrm{H}_{4}$, with smaller amounts of $\mathrm{H}_{2}$, $\mathrm{C}_{2} \mathrm{H}_{2}, \mathrm{C}_{2} \mathrm{H}_{6}$, and $\mathrm{C}_{3}-\mathrm{C}_{4}$ hydrocarbons also present. The results confirmed that the ignition process is particularly sensitive to air temperature, $T_{\text {air }}$, and is greatly facilitated at the higher $T_{\text {air }}$ 's that correspond to the higher $M_{\infty}$ 's $(c f$. Eqs. 1 and 2). $T_{\text {fuel }}=950 \mathrm{~K}$ and $p=1 \mathrm{~atm}$ was assumed throughout the study. The study also revealed that ignition behavior is controlled by the synergistic effect of $\mathrm{CH}_{4}$ and $\mathrm{C}_{2} \mathrm{H}_{4}$, with $\mathrm{CH}_{4}$ inhibiting ignition of $\mathrm{C}_{2} \mathrm{H}_{4}$ at the higher $T_{\text {air }}$ values. For (the lower value) of $T_{\text {air }}=1050 \mathrm{~K}$, however, small additions of $\mathrm{CH}_{4}$ were found to moderately promote the ignition process. Large additions of $\mathrm{CH}_{4}$ inhibited $\mathrm{C}_{2} \mathrm{H}_{4}$ ignition under all conditions investigated. For the less favorable $T_{\text {air }}=1050 \mathrm{~K}$, that corresponds to the lower limit of the proposed $M_{\infty}$ range, ignition strain rates, $\sigma_{\text {ign }}$, of such fuel blends were found to be of the order of $10^{2} / \mathrm{s}$ to $10^{3} / \mathrm{s}$, substantially lower than anticipated strain rates in a SCRAMJET.

In order to increase the values of $\sigma_{\text {ign }}$ for the lower $T_{\text {air }}=1050 \mathrm{~K}$ case, additives such as $\mathrm{H}_{2}$ and $\mathrm{F}_{2}$ were independently supplemented into the fuel and air streams, respectively. As expected, addition of $\mathrm{H}_{2}$ promoted ignition and values of $\sigma_{\text {ign }} \simeq$ $4,000 / \mathrm{s}$ were found for a $10 \%$ molar fraction of $\mathrm{H}_{2}$ in the fuel-blend. Similarly, a $1 \%$ molar fraction of $\mathrm{F}_{2}$ in the air stream resulted in a similar value of $\sigma_{\text {ign }} \simeq 4,000 / \mathrm{s}$. While ignition promotion through $\mathrm{H}_{2}$ addition was found to be caused by efficient 
H-radical production, ignition promotion through $\mathrm{F}_{2}$ addition was found to result from the additional fuel consumption by F-radicals.

Hydrocarbon oxidation is also known to be promoted in the presence of NO and extensive pertinent studies in homogeneous systems and flames have been conducted (e.g., Bromly et al. 1992, Doughty et al. 1996, Law 1998, Marinov et al. 1998, Nelson et al. 1994, Tan et al. 1999). The main mechanism supporting the observed oxidation promotion, is $\mathrm{NO}$ reactions with $\mathrm{RO}_{2}$, where $\mathrm{R}=\mathrm{H}$, or an alkyl group, that produce $\mathrm{RO}$ and $\mathrm{NO}_{2}$ (e.g., Doughty et al. 1996). Subsequently, RO can decompose to $\mathrm{H}$ radicals that are essential to the overall oxidation process. For the special case of $\mathrm{NO}$ reacting with $\mathrm{HO}_{2}, \mathrm{OH}$ radicals, which are very effective in consuming hydrocarbons, are readily produced. Thus, through these NO-induced reactions, highly-reactive $\mathrm{OH}$ and $\mathrm{H}$ radicals are readily produced from the relatively unreactive $\mathrm{RO}_{2}$ radicals. These studies have also revealed that the extent of the observed oxidation promotion depends on the hydrocarbon type. For example, the recent flow reactor study of Marinov et al. (1998) has shown that $\mathrm{C}_{2} \mathrm{H}_{4}$ and $\mathrm{C}_{3} \mathrm{H}_{8}$ interact more effectively with $\mathrm{NO}$, compared to $\mathrm{CH}_{4}$. The also recent flame-ignition studies of Law and coworkers (Law 1998, Tan et al. 1999) revealed that the presence of $\mathrm{NO}$ reduces the ignition temperature of hydrocarbons, with $\mathrm{CH}_{4}$ and $\mathrm{C}_{3} \mathrm{H}_{8}$ being more sensitive to $\mathrm{NO}$ addition, compared to $\mathrm{C}_{2} \mathrm{H}_{6}$ and $\mathrm{i}-\mathrm{C}_{4} \mathrm{H}_{10}$.

The ignition studies of Law and coworkers (Law 1998, Tan et al. 1999) assessed the behavior of selected saturated hydrocarbons and $\mathrm{H}_{2}$. The ignition/extinction characteristics of $\mathrm{C}_{2} \mathrm{H}_{4}$ and its blends with other cracked-fuel hydrocarbons, as well as the effects of such additives as $\mathrm{H}_{2}$ and $\mathrm{F}_{2}$, and $\mathrm{NO}$ were studied by ED98. The ignition sensitivity of pure $\mathrm{C}_{2} \mathrm{H}_{4}$ to additives was not examined in these studies. $\mathrm{C}_{2} \mathrm{H}_{4}$ is a main constituent of thermal cracking of jet fuel, with ignition characteristics that are superior to those of $\mathrm{CH}_{4}$, the other main constituent. Thus, if ignition strain rates approriate for SCRAMJET operation are to be achieved, $\mathrm{C}_{2} \mathrm{H}_{4}$ must be independently considered.

The main objective of this work is to extend previous studies by considering the non-premixed ignition/extinction characteristics of additives, such as NO, on pure $\mathrm{C}_{2} \mathrm{H}_{4}$, for temperatures of relevance to SCRAMJET's. NO is expected to have a noticeable effect in promoting $\mathrm{C}_{2} \mathrm{H}_{4}$ ignition, as was reported by Marinov 
et al. (1998). Furthermore, NO can be inherently present in, or added to, air with effects on engine materials that are benign compared to $\mathrm{F}_{2}$. The study also assesses the relative effect of $\mathrm{NO}$ and other additives on pure $\mathrm{C}_{2} \mathrm{H}_{4}$ ignition, such as $\mathrm{F}_{2}$ and $\mathrm{H}_{2}$.

\section{Numerical method}

The main effects of the imposed flow environment on ignition can be quantified in opposed-jet configurations in terms of the hydrodynaamic strain rate, defined as the maximum absolute value of the velocity gradient on the air side, just before the ignition kernel, i.e.,

$$
\sigma \equiv\left|\frac{\partial u}{\partial x}\right|_{\max , \text { air side }} .
$$

The air side is chosen for the definition of $\sigma$, as the rate of transport of $\mathrm{O}_{2}$ in the hydrodynamic zone determines the extent of its leakage through the main reaction zone. This quantity is well-defined and can be well-controlled ( $c f$. Kreutz \& Law 1996 and Fotache et al. 1997a, 1997b).

An additional advantage of this configuration is that the flow-field is quasi onedimensional in the vicinity of the centerline. Thus, the simulations are conducted by solving the one-dimensional, steady, conservation equations of mass, momentum, energy, and species concentrations along the stagnation streamline. The pertinent equations and boundary conditions can be found in Egolfopoulos (1994a) and Egolfopoulos \& Campbell (1996).

Similarly to the ED98 study on non-premixed hydrocarbon ignition, the original stagnation-flow code (Kee 1990), subsequently modifed for non-premixed flames (Egolfopoulos 1994b), was further modified by implementing a two-point continuation approach to capture the entire S-curve behavior (e.g., Williams 1985). This approach was first introduced by Nishioka et al. (1996) and imposes a pre-determined temperature, or species mass fraction reduction, at two points in the flow field. Thus, the strain rate is solved for, rather than imposed as a boundary condition. Locations where the temperature or species concentrations have maximum slopes were chosen to be the two points, following the recommendations of Nishioka et 
al. (1996). In the present study, the two-point continuation approach is applied to $\mathrm{H}$ radicals, although any other radical can be used (Nishioka et al. 1996). A steady solution is first established under conditions of vigorous burning at relatively low strain rates. Subsequently, H-radical mass fraction is incrementally reduced, permitting all S-curve branches, stable and unstable, to be determined.

\begin{tabular}{|c|c|c|c|c|}
\hline & Reaction & $A$ & $n$ & $E_{\mathrm{a}}$ \\
\hline $\mathrm{R} 295$ & $\mathrm{NO}+\mathrm{F}_{2} \rightarrow \mathrm{FNO}+\mathrm{F}$ & $4.20 \mathrm{E} 11$ & 0.00 & 2285 \\
\hline $\mathrm{R} 296$ & $\mathrm{NO}+\mathrm{F}+\mathrm{M} \rightarrow \mathrm{FNO}+\mathrm{M}$ & $3.00 \mathrm{E} 16$ & 0.00 & 0 \\
\hline $\mathrm{R} 297$ & $\mathrm{H}+\mathrm{F}_{2} \rightarrow \mathrm{HF}+\mathrm{F}$ & 2.90E09 & 1.40 & 1325 \\
\hline $\mathrm{R} 298$ & $\mathrm{~F}+\mathrm{H}_{2} \rightarrow \mathrm{HF}+\mathrm{H}$ & $2.70 \mathrm{E} 12$ & 0.50 & 634 \\
\hline R299 & $\mathrm{F}_{2}+\mathrm{M} \rightarrow \mathrm{F}+\mathrm{F}+\mathrm{M}$ & 2.10E13 & 0.00 & 33700 \\
\hline R300 & $\mathrm{HF}+\mathrm{M} \rightarrow \mathrm{H}+\mathrm{F}+\mathrm{M}$ & 1.10E19 & -1.00 & 134100 \\
\hline R301 & $\mathrm{C}_{2} \mathrm{H}_{4}+\mathrm{F} \rightarrow \mathrm{C}_{2} \mathrm{H}_{3}+\mathrm{HF}$ & $1.00 \mathrm{E} 14$ & 0.00 & 2000 \\
\hline R302 & $\mathrm{C}_{2} \mathrm{H}_{3}+\mathrm{F} \rightarrow \mathrm{C}_{2} \mathrm{H}_{2}+\mathrm{HF}$ & $2.00 \mathrm{E} 13$ & 0.00 & 0 \\
\hline R303 & $\mathrm{C}_{2} \mathrm{H}_{2}+\mathrm{F} \rightarrow \mathrm{C}_{2} \mathrm{H}+\mathrm{HF}$ & $5.00 \mathrm{E} 13$ & 0.00 & 0 \\
\hline R304 & $\mathrm{OH}+\mathrm{F} \rightarrow \mathrm{O}+\mathrm{HF}$ & 2.00E13 & 0.00 & 0 \\
\hline R305 & $\mathrm{HO}_{2}+\mathrm{F} \rightarrow \mathrm{O}_{2}+\mathrm{HF}$ & $2.89 \mathrm{E} 12$ & 0.50 & 0 \\
\hline R306 & $\mathrm{H}_{2} \mathrm{O}+\mathrm{F} \rightarrow \mathrm{OH}+\mathrm{HF}$ & 1.30E09 & 1.50 & 0 \\
\hline R307 & $\mathrm{H}_{2} \mathrm{O}_{2}+\mathrm{F} \rightarrow \mathrm{HO}_{2}+\mathrm{HF}$ & $1.73 \mathrm{E} 12$ & 0.50 & 0 \\
\hline R308 & $\mathrm{CH}_{3}+\mathrm{F} \rightarrow \mathrm{CH}_{2}(\mathrm{~s})+\mathrm{HF}$ & $1.62 \mathrm{E} 16$ & -0.88 & -981 \\
\hline R309 & $\mathrm{CH}_{4}+\mathrm{F} \rightarrow \mathrm{CH}_{3}+\mathrm{HF}$ & $5.90 \mathrm{E} 12$ & 0.50 & 450 \\
\hline R310 & $\mathrm{CH}_{3} \mathrm{OH}+\mathrm{F} \rightarrow \mathrm{CH}_{3} \mathrm{O}+\mathrm{HF}$ & 2.62E09 & 1.44 & -205 \\
\hline R311 & $\mathrm{CH}_{3} \mathrm{OH}+\mathrm{F} \rightarrow \mathrm{CH}_{2} \mathrm{OH}+\mathrm{HF}$ & $4.62 \mathrm{E} 07$ & 1.97 & -300 \\
\hline R312 & $\mathrm{CH}_{2} \mathrm{O}+\mathrm{F} \rightarrow \mathrm{HCO}+\mathrm{HF}$ & $6.00 \mathrm{E} 13$ & 0.00 & 2000 \\
\hline $\mathrm{R} 313$ & $\mathrm{CH}_{3} \mathrm{O}+\mathrm{F} \rightarrow \mathrm{CH} 2 \mathrm{O}+\mathrm{HF}$ & $3.00 \mathrm{E} 13$ & 0.00 & 0 \\
\hline R314 & $\mathrm{HCO}+\mathrm{F} \rightarrow \mathrm{CO}+\mathrm{HF}$ & $1.00 \mathrm{E} 13$ & 0.00 & 0 \\
\hline R315 & $\mathrm{C}_{2} \mathrm{H}_{6}+\mathrm{F} \rightarrow \mathrm{C}_{2} \mathrm{H}_{5}+\mathrm{HF}$ & 8.00E12 & 0.00 & 300 \\
\hline
\end{tabular}

Table 1. $\mathrm{H}_{2} / \mathrm{NO} / \mathrm{F}_{2} /$ hydrocarbon $/ \mathrm{O}_{2}$ parameters: $k=A T^{n} e^{-E_{\mathrm{a}} / R T}, A$ in molcm-s, $E_{\mathrm{a}}$ in cal/mol. Refs 1: Egolfopoulos et al. (1996), 2: Wang \& Frenklach (1997), 3: Burgess et al. (1997), and 4: Westmoreland (1997).

The code was integrated into the CHEMKIN (Kee et al. 1989) and Transport (Kee et al. 1983) subroutine packages. The kinetic mechanism of Wang \& Frenklach (1997), with 50 species and 294 reactions, was adopted. This mechanism describes the oxidation characteristics of $\mathrm{C}_{1}$ - and $\mathrm{C}_{2}$-hydrocarbons and $\mathrm{N}_{2}$-related chemistry, 
and was developed for $\mathrm{C}_{2} \mathrm{H}_{4}$ and $\mathrm{C}_{2} \mathrm{H}_{2}$ flames, while retaining the main features of the GRI 2.1 mechanism (Bowman et al. 1995). The use of the Wang \& Frenklach mechanism is essential, as the GRI 2.1 mechanism does not include the $\mathrm{CH}_{2} \mathrm{CHO}$ (vinyoxy) radical species that plays an essential role in $\mathrm{C}_{2} \mathrm{H}_{4}$ ignition. It was found in ED98 that omitting $\mathrm{CH}_{2} \mathrm{CHO}$ and its reactions leads to an underestimation of the ignition strain rate, $\sigma_{\text {ign }}$, by a factor of 30 , or so. The Wang \& Frenklach mechanism is augmented by four species $\left(\mathrm{F}_{2}, \mathrm{FNO}, \mathrm{HF}\right.$, and $\left.\mathrm{F}\right)$ and 21 reactions (Table 1 ) that describe couplings between $\mathrm{H}_{2}$, hydrocarbons, $\mathrm{NO}$, and $\mathrm{F}_{2}$. This was motivated by the results of previous experiments (Mungal \& Dimotakis 1984) and numerical-simulation studies (Egolfopoulos et al. 1996), where the simultaneous presence of small quantities of $\mathrm{F}_{2}$ and $\mathrm{NO}$ was found to enhance overall radical production. Reactions between hydrocarbons and $\mathrm{F}_{2}$ are taken from Burgess et al. (1997) and Westmoreland (1997). Reactions between the $\mathrm{F}_{2}$ and NO are adopted as in Egolfopoulos et al. (1996).

\section{Results and discussion}

Similarly to the ED98 ignition study, the simulations are conducted for $T_{\text {fuel }}=$ $950 \mathrm{~K}$. Air temperature is chosen to be $T_{\text {air }}=1050 \mathrm{~K}$, for which ignition characteristics thermal cracking products, including $\mathrm{C}_{2} \mathrm{H}_{4}$, are rather poor. Details of the ignition process and the controlling mechanisms are identified by conducting structure, sensitivity, reaction-path, and integrated species-consumption path analyses in the vicinity of the "ignition kernel", as originally identified by Kreutz \& Law (1996). The details of the sensitivity analysis in flames are described by Kee et al. (1985). The integrated species-consumption path analysis is obtained by a spatial integration of the species-consumption rates and by subsequent identification of the dominant kinetic paths. The response of the reacting non-premixed system to $\sigma$ (Eq. 3) is presented through the variation of the maximum H-radical mass fraction, $\left(Y_{\mathrm{H}}\right)_{\max }$, with $\sigma$. 


\subsection{S-curve response of $\mathrm{C}_{2} \mathrm{H}_{4}$ /air}

The S-curve response of $\mathrm{C}_{2} \mathrm{H}_{4}$ /air is shown in Fig. 1. Point A denotes a condition of vigorous burning, $\mathrm{B}$ extinction, $\mathrm{E}$ ignition, and $\mathrm{F}$ a pre-ignition condition characterized by low overall reaction intensity. Points $\mathrm{C}$ and D are located in the unstable branch of the S-curve and resemble conditions of "intermediate" stages of (unstable) ignition and extinction respectively. The detailed response of the $\sigma_{\text {ign }}$ to $T_{\text {air }}$ (results from ED98) is shown in the inset in Fig. 1, with symbols denoting values determined from the simulations and the solid line a smooth least-square-fit to aid the eye. The large sensitivity of $\sigma_{\text {ign }}$ to $T_{\text {air }}$ is evident.

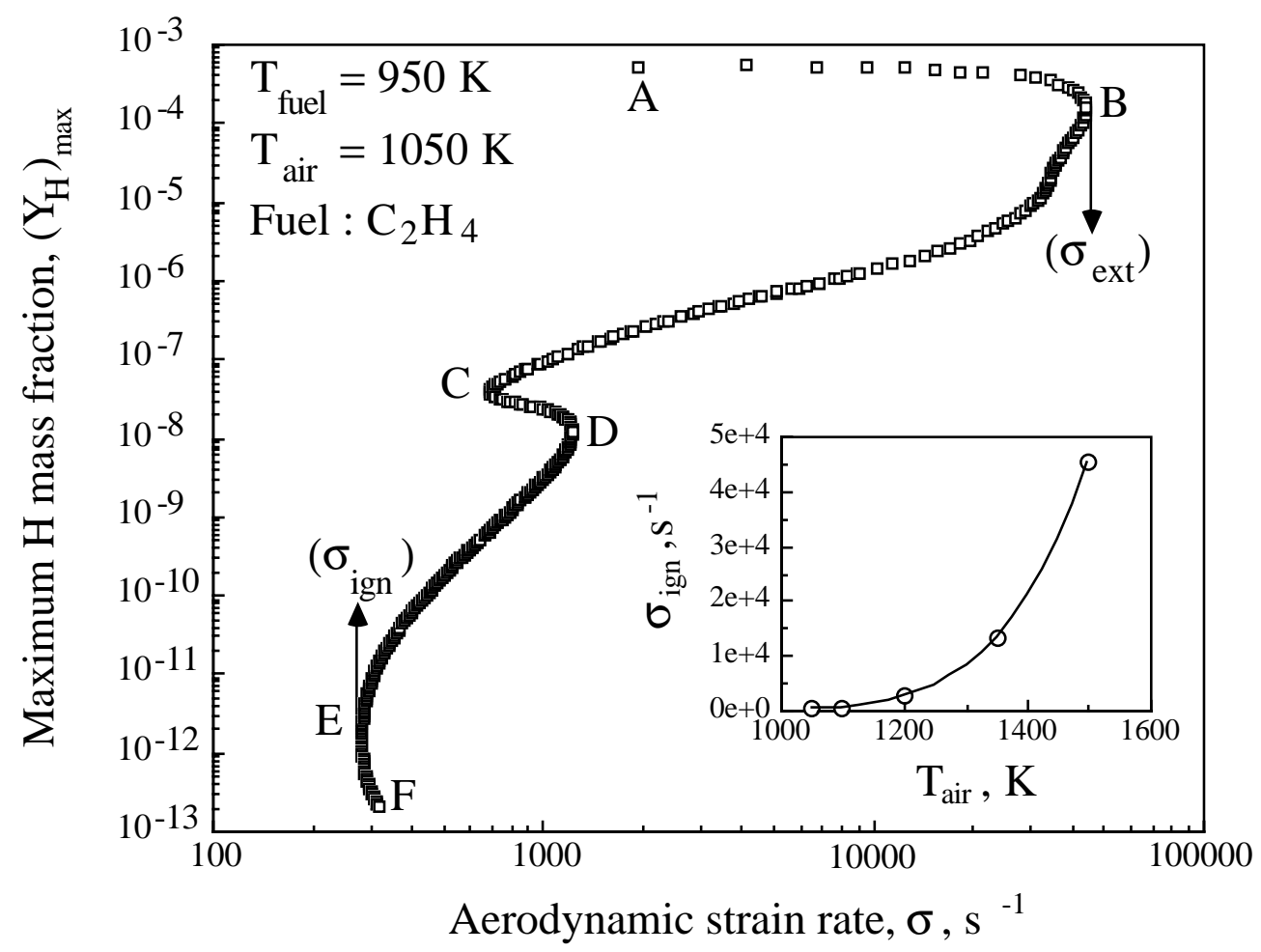

Fig. 1 S-curve response of $\mathrm{C}_{2} \mathrm{H}_{4} /$ air $\left(T_{\text {air }}=1050 \mathrm{~K}, T_{\text {fuel }}=950 \mathrm{~K}\right)$. Inset figure plots $\sigma_{\text {ign }}$ (circles) with least-square smooth fit curve to aid the eye (ED98).

The dominant mechanisms of the various S-curve branches are revealed by the structure of the ignition kernel. As reported in the ED98 study, in the pre-ignition Region $\mathrm{F}, \mathrm{C}_{2} \mathrm{H}_{4}$ is largely consumed through reactions (numbers correspond to the order in which the reactions appear in the kinetic mechanism),

R165 (30\%)

$\mathrm{C}_{2} \mathrm{H}_{4}+\mathrm{O} \longrightarrow \mathrm{CH}_{3}+\mathrm{HCO}$, 

R167 (18\%)
$\mathrm{C}_{2} \mathrm{H}_{4}+\mathrm{CH}_{3} \longrightarrow \mathrm{C}_{2} \mathrm{H}_{3}+\mathrm{CH}_{4}$,
R166 (16\%)
$\mathrm{C}_{2} \mathrm{H}_{4}+\mathrm{OH} \longrightarrow \mathrm{C}_{2} \mathrm{H}_{3}+\mathrm{H}_{2} \mathrm{O}$,
R163 (16\%)
$\mathrm{C}_{2} \mathrm{H}_{4}+\mathrm{H}+\mathrm{M} \longrightarrow \mathrm{C}_{2} \mathrm{H}_{5}+\mathrm{M}$.

$\mathrm{CH}_{3}$ produced by R165 is largely consumed by $\mathrm{R} 167$. Thus, $\mathrm{C}_{2} \mathrm{H}_{3}$ is the main product of $\mathrm{C}_{2} \mathrm{H}_{4}$ consumption. $\mathrm{C}_{2} \mathrm{H}_{3}$ is consumed by the low-activation-energy reactions,
R160 (53\%)
$\mathrm{C}_{2} \mathrm{H}_{3}+\mathrm{O}_{2} \longrightarrow \mathrm{CH}_{2} \mathrm{CHO}+\mathrm{O}$,
R161 (44\%)
$\mathrm{C}_{2} \mathrm{H}_{3}+\mathrm{O}_{2} \longrightarrow \mathrm{HCO}+\mathrm{CH}_{2} \mathrm{O}$.

vinyoxy radical, $\mathrm{CH}_{2} \mathrm{CHO}$, is entirely decomposed through the reaction ('-' denotes reverse reaction),

$\mathrm{R} 182-(100 \%) \quad \mathrm{CH}_{2} \mathrm{CHO}+\mathrm{M} \longrightarrow \mathrm{CH}_{2} \mathrm{CO}+\mathrm{H}+\mathrm{M}$,

that is the main source of $\mathrm{H}$ radicals. $\mathrm{H}$ radicals, in turn, are consumed by $\mathrm{R} 163(60 \%)$ and the main branching reaction,

$\mathrm{R} 1 \quad \mathrm{H}+\mathrm{O}_{2} \longrightarrow \mathrm{OH}+\mathrm{O}$,

that produces the $\mathrm{O}$ and $\mathrm{OH}$ radicals essential for fuel consumption and, thus, ignition.

Given the importance of H-radicals to the ignition process, as they are essential for the progress of R1, we may conclude that the kinetics of $\mathrm{CH}_{2} \mathrm{CHO}$ play a crucial role in the pre-ignition Region $\mathrm{F}$. The omission of such species result in substantial underprediction of $\sigma_{\text {ign }}$ of $\mathrm{C}_{2} \mathrm{H}_{4}$ ( $c f$. ED98).

The chemical-kinetic processes in the pre-ignition Region $\mathrm{F}$ are quite slow compared to the transport processes the extent of which is imposed by the fluid mechanics. As $\sigma$ is reduced, Point E is eventually reached, where the rate of radical production exceeds the convective/diffusive radical loss rate out of the ignition kernel (Kreutz \& Law 1996), and ignition occurs. At Point E, $\mathrm{C}_{2} \mathrm{H}_{4}$ is entirely consumed by $\mathrm{H}, \mathrm{O}, \mathrm{OH}$, and $\mathrm{CH}_{3}$ radicals, with virtually no heat release. Thus, for the present reactant initial conditions, $\mathrm{C}_{2} \mathrm{H}_{4}$ ignition is caused by radical runaway rather than thermal runaway, similarly to $\mathrm{H}_{2}$ (Kreutz \& Law 1996). This 
is physically reasonable, as the reactions responsible for $\mathrm{C}_{2} \mathrm{H}_{4}$ consumption and H-radical production are characterized by low activation energies. The sensible energy supplied by the reactant streams is sufficient for the effective progress of the radical-producing reactions and no additional heat release is required.

The non-monotonic behavior of the S-curve at Points C and D was also assessed. While these conditions are physically unstable, they are possible (mathematical) solutions. It was found that between Regions F and D the contribution of R166 to fuel consumption, i.e., through $\mathrm{OH}$, increases by following the solution path from Region F and moving towards D, with R166 the main fuel-consuming reaction as the radical pool increases. Within this region, the contribution of $\mathrm{R} 1$ to $\mathrm{OH}$ production is reduced at the higher radical concentrations, as substantial amounts of $\mathrm{H}_{2} \mathrm{O}_{2}$ are produced through the radical-radical recombination reaction,

$\mathrm{R} 23$

$$
\mathrm{HO}_{2}+\mathrm{HO}_{2}+\mathrm{M} \longrightarrow \mathrm{H}_{2} \mathrm{O}_{2}+\mathrm{M}
$$

radical-radical reactions are unimportant for low radical concentrations. Subsequently, $\mathrm{H}_{2} \mathrm{O}_{2}$ readily decomposes to $2 \mathrm{OH}$ through the reaction,

$\mathrm{R} 16$

$$
\mathrm{H}_{2} \mathrm{O}_{2}+\mathrm{M} \longrightarrow 2 \mathrm{OH}+\mathrm{M}
$$

Thus, the contribution of R16 to $\mathrm{OH}$ production monotonically increases, over that of R1 at higher radical concentrations, with the kinetics of $\mathrm{HO}_{2}$ and $\mathrm{H}_{2} \mathrm{O}_{2}$ controlling the system response. Given the low diffusivity of these species, steady solutions are obtained at lower values of $\sigma$ and that explains the turning behavior in Region D. At this point, the maximum rate of $\mathrm{R} 23$ is equal to that of $\mathrm{R} 1$. As Point $\mathrm{C}$ is approached, intensified $\mathrm{OH}$ production results in heat release that further facilitates the decomposition reaction R16. Just before Point $\mathrm{C}$, the maximum rate of R16 exceeds that of $\mathrm{R} 1$ and as Point $\mathrm{C}$ is reached, $\mathrm{OH}$ production is such that sufficient heat is released to cause this ignition-type, turning-point behavior. The variation of the maximum reaction rates of $\mathrm{R} 1, \mathrm{R} 16$, and $\mathrm{R} 23$ is shown in Fig. 2 . 


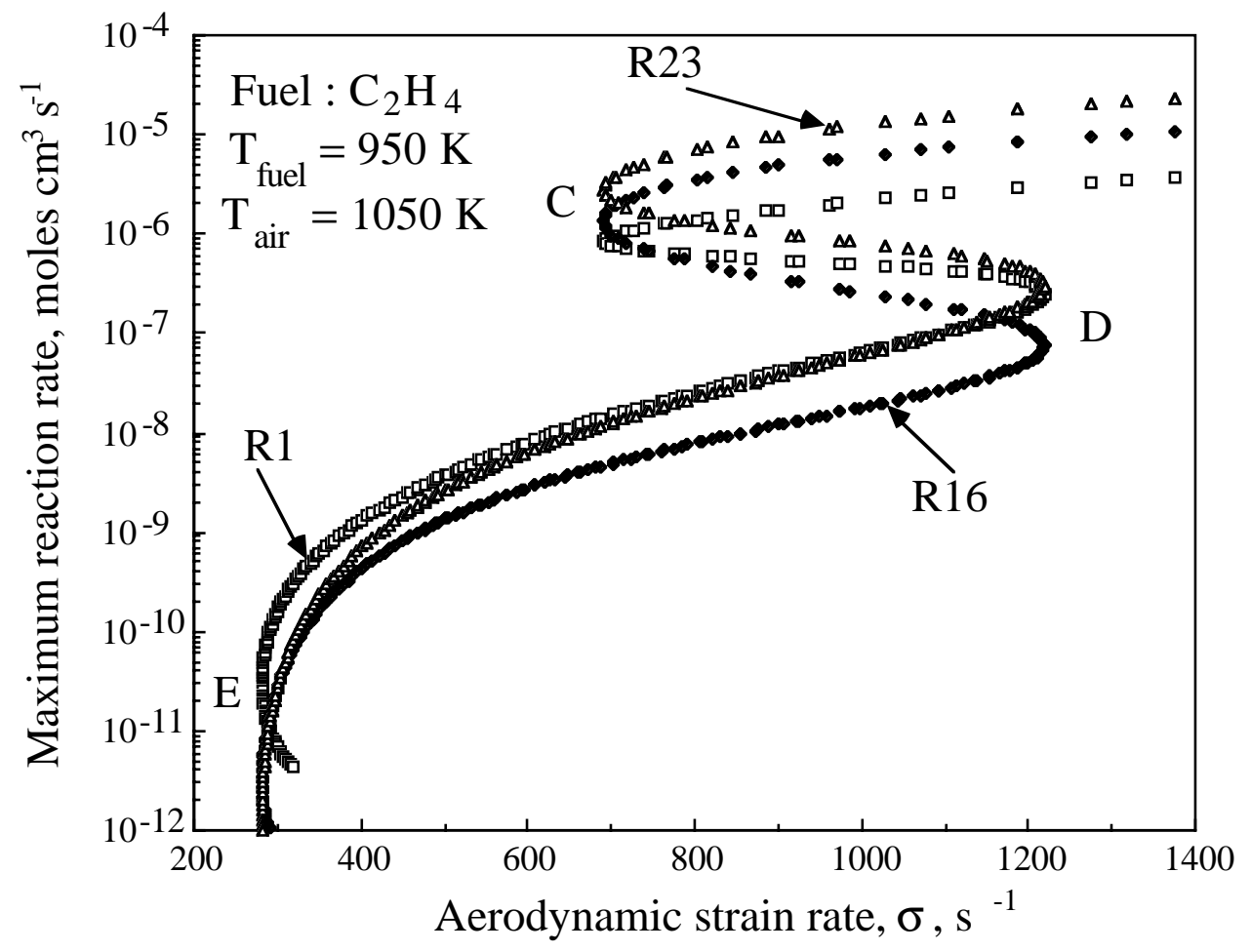

FIG. 2 Effect of strain rate on the maximum rates of Reactions R1, R16, and R23 for $\mathrm{C}_{2} \mathrm{H}_{4} /$ air $\left(T_{\text {air }}=1050 \mathrm{~K}, T_{\text {fuel }}=950 \mathrm{~K}\right.$.

\subsection{NO addition}

The effect of NO as an additive was investigated by adding it in amounts ranging from 500 to $50,000 \mathrm{ppm}$, on a molar basis, into the reactant streams. The resulting S-curves are shown in Figs. 3 and 4, for NO additions into the air and fuel streams, respectively.

As can be seen, the presence of NO causes a substantial increase of $\sigma_{\text {ign }}$, especially when NO is added on the air side. For example, addition of $500 \mathrm{ppm}$ of NO increases the $\sigma_{\text {ign }}$ by a factor of 8 , while $\sigma_{\text {ign }}$ 's as high as $32,000 /$ s are achieved with NO additions up to 10,000 ppm. Through NO addition, ignition takes place at higher radical concentrations corresponding to the Region C-D of Fig. 1. As mentioned above, in the absence of NO, this region represents an unstable-ignition regime. Furthermore, these higher radical concentrations result in noticeable heat release that becomes a factor in the ignition process. It is also seen that NO can affect extinction as well, especially when added on the air side. 


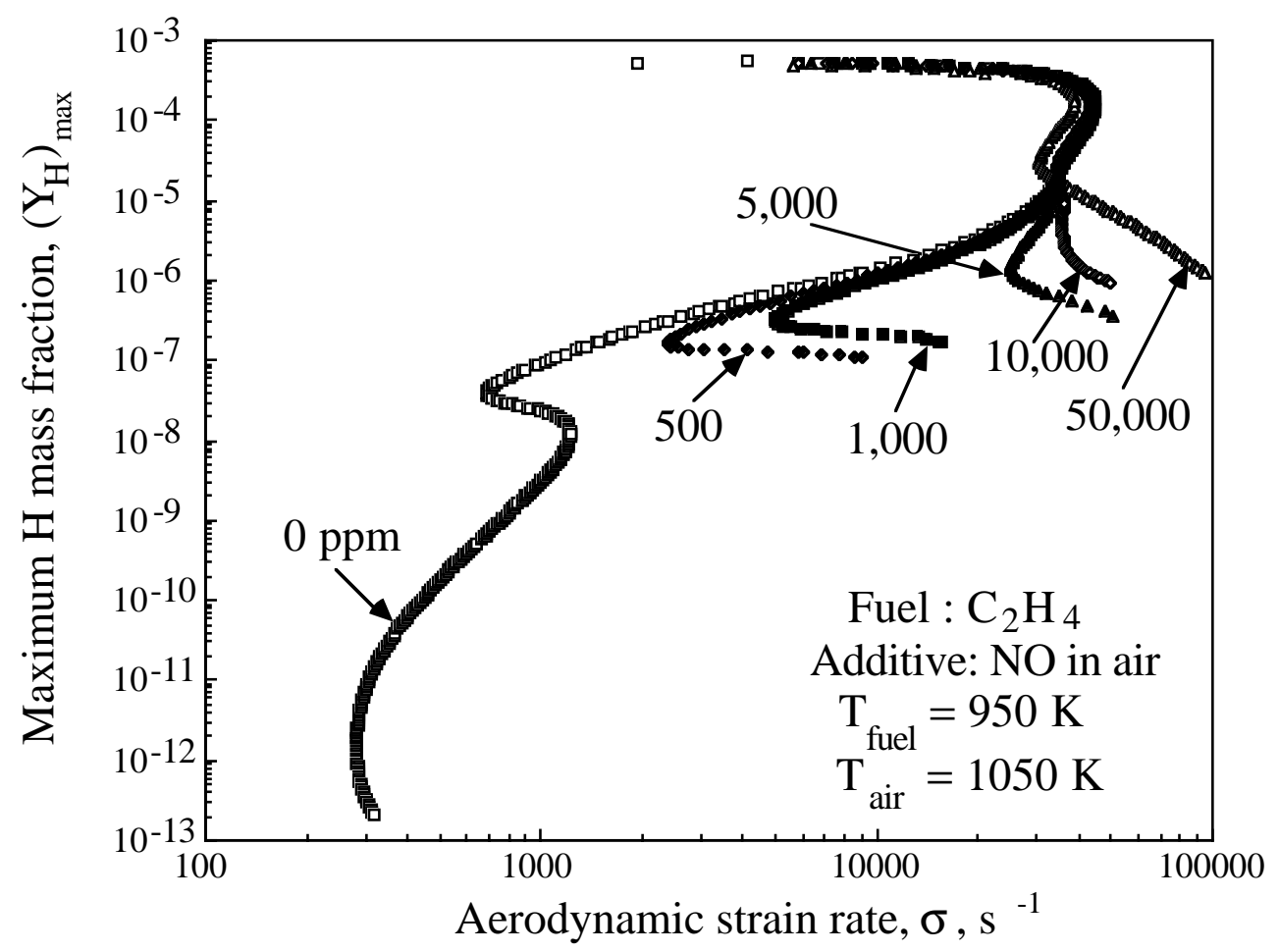

FIG. 3 Effect of $\mathrm{NO}$ addition on S-curve response of $\mathrm{C}_{2} \mathrm{H}_{4} /$ air $\left(T_{\text {air }}=1050 \mathrm{~K}\right.$, $\left.T_{\text {fuel }}=950 \mathrm{~K}\right)$. NO added to air stream.

Figures 5a and 5b depict the variation of $\sigma_{\text {ign }}$ and the extinction strain rate, $\sigma_{\text {ext }}$, respectively, with NO addition. Figure 5 a shows that the sensitivity of $\sigma_{\text {ign }}$ to NO is high up to about $10,000 \mathrm{ppm}$. For larger amounts of NO, the values of $\sigma_{\text {ign }}$ level off when $\mathrm{NO}$ is added on the fuel side, while a moderate reduction in $\sigma_{\text {ign }}$ is observed when NO is added on the air side. Furthermore, for additions below $10,000 \mathrm{ppm}$, NO is more effective in increasing $\sigma_{\text {ign }}$ when added on the air side. Figure $5 \mathrm{~b}$ also shows that when NO is added on the air side, $\sigma_{\text {ext }}$ moderately increases for small amounts (i.e., $<1000 \mathrm{ppm}$ ), while noticeably decreasing for larger amounts of NO. NO addition on the fuel side results in a moderate increase of $\sigma_{\text {ext }}$, which remains nearly-constant for amounts up to 50,000 ppm.

The effect of NO on ignition was analyzed for 5,000 ppm and 50,000 ppm added on the air side. The 5,000 ppm case was chosen as representative of the promoting behavior of NO on ignition. The 50,000 ppm case was chosen to study the reduced promoting effect of NO, when added in large amounts. 


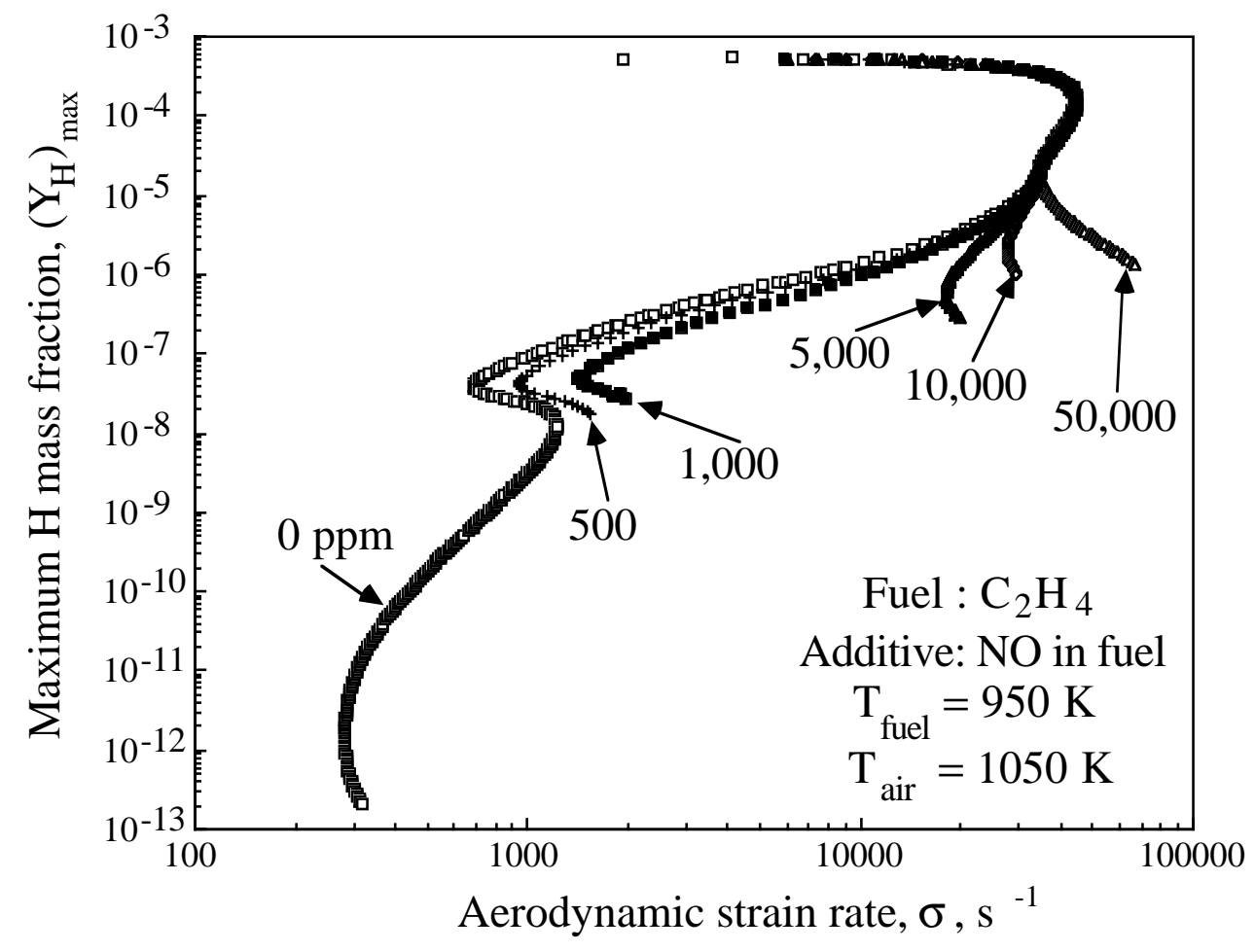

Fig. 4 Effect of NO addition on S-curve response of $\mathrm{C}_{2} \mathrm{H}_{4} /$ air $\left(T_{\text {air }}=1050 \mathrm{~K}\right.$, $\left.T_{\text {fuel }}=950 \mathrm{~K}\right)$. NO added to fuel stream.

At ignition for the $5,000 \mathrm{ppm}$ case, $\mathrm{C}_{2} \mathrm{H}_{4}$ is consumed through $\mathrm{R} 166(47 \%)$, $\mathrm{R} 165(28 \%)$, and R163 (19\%). It is apparent that $\mathrm{OH}$ is largely responsible for the fuel consumption, with a role that is substantially enhanced, as compared to the case of pure $\mathrm{C}_{2} \mathrm{H}_{4}$ ignition, described earlier. This behavior is attributable to a sequence of reactions with $\mathrm{NO}$ that results in the enhancement of OH-radical production. More specifically, $\mathrm{OH}$ is produced through reactions,
R91 (35\%)
$\mathrm{CH}_{3}+\mathrm{HO}_{2} \longrightarrow \mathrm{CH}_{3} \mathrm{O}+\mathrm{OH}$
R201 (28\%)
$\mathrm{NO}+\mathrm{HO}_{2} \longrightarrow \mathrm{NO}_{2}+\mathrm{OH}$
R204 (16\%)
$\mathrm{NO}_{2}+\mathrm{H} \longrightarrow \mathrm{NO}+\mathrm{OH}$,
R19 (13\%)
$\mathrm{H}+\mathrm{HO}_{2} \longrightarrow \mathrm{OH}+\mathrm{OH}$.

At the same time, NO is entirely (97\%) consumed through R201.

Thus, $\mathrm{NO}$ is converted to $\mathrm{NO}_{2}$ through $\mathrm{R} 201$ and is, subsequently, reduced back to NO through R204. This cyclic, "catalytic" behavior of NO has been noted 


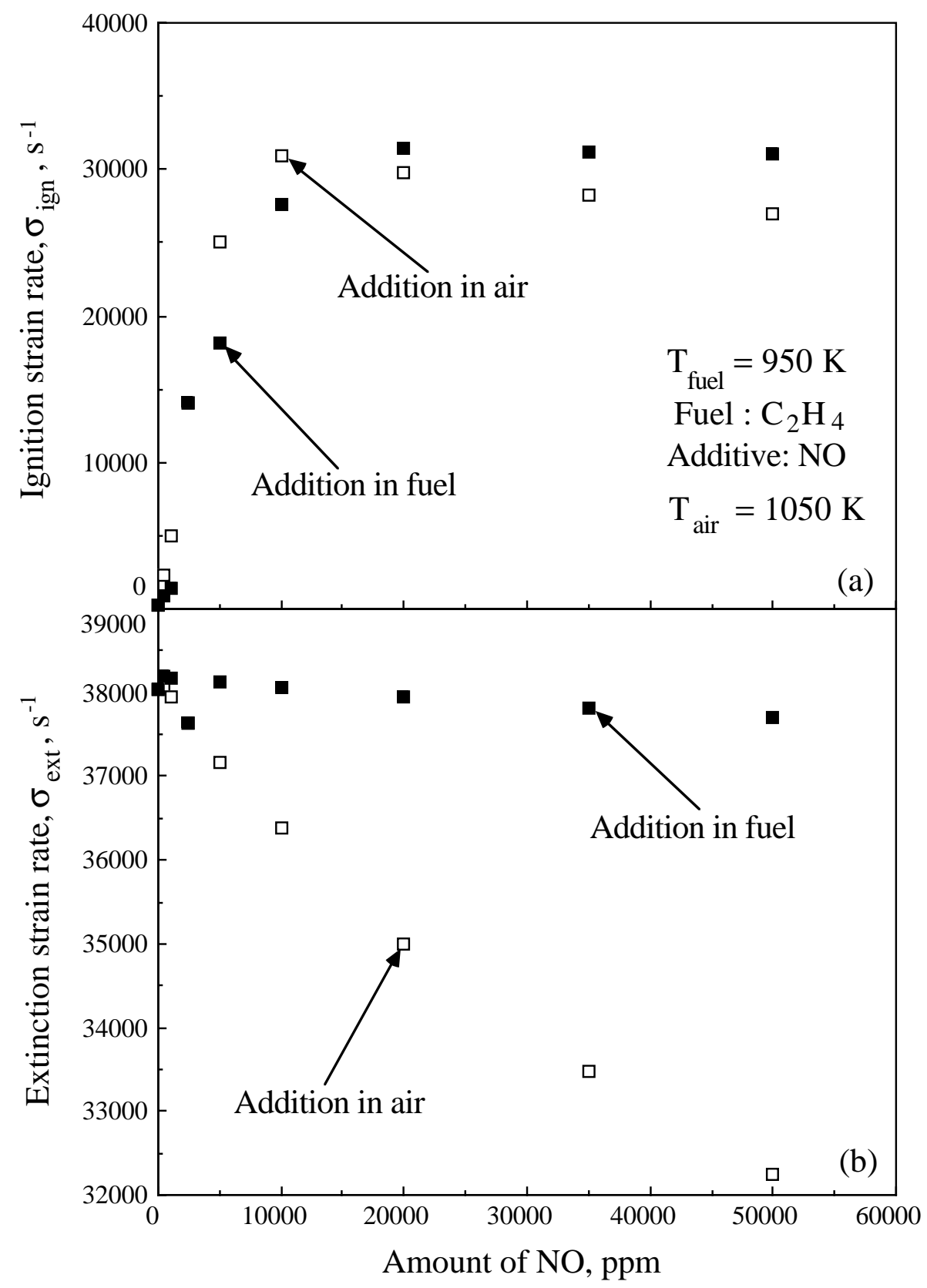

Fig. 5 Effect of $\mathrm{NO}$ addition on (a) $\sigma_{\text {ign }}$ and (b) $\sigma_{\text {ext }}$ of $\mathrm{C}_{2} \mathrm{H}_{4} /$ air $\left(T_{\text {air }}=1050 \mathrm{~K}\right.$, $\left.T_{\text {fuel }}=950 \mathrm{~K}\right)$.

previously (e.g., Bromly et al. 1992, Doughty et al. 1996, Law 1998, Marinov et al. 1998, Nelson \& Haynes 1994, Tan et al. 1999), and enhances production of the fuel-scavenger $\mathrm{OH}$ radicals. It is noteworthy that R201 and R204 are responsible for an overall, NO-induced, branching-like reaction, $\mathrm{H}+\mathrm{HO}_{2} \rightarrow 2 \mathrm{OH}$, which can also proceed as an elementary step through R19, independently of NO. This point 
was further assessed by determining that $\mathrm{HO}_{2}$ is consumed through $\mathrm{R} 91(34 \%)$, $\mathrm{R} 201(28 \%)$, and R19(13\%). As a result, the NO is responsible for a more effective conversion of $\mathrm{HO}_{2}$ to $\mathrm{OH}$ radicals, as compared to $\mathrm{R} 19$.

Marinov et al. (1998) indicated that $\mathrm{C}_{2} \mathrm{H}_{4}$ ignition is particularly sensitive to $\mathrm{NO}$ addition because of the efficient production of $\mathrm{HO}_{2}$ radicals during the $\mathrm{C}_{2} \mathrm{H}_{4}$ oxidation. More specifically, at the ignition point, $\mathrm{HO}_{2}$ is largely produced by the reaction (the percentage here refers to $\mathrm{HO}_{2}$-production contribution),

R50

$$
\mathrm{HCO}+\mathrm{O}_{2} \longrightarrow \mathrm{CO}+\mathrm{HO}_{2},
$$

so that the $\mathrm{HO}_{2}$ production rate directly depends on $\mathrm{HCO}$ concentration. As $\mathrm{C}_{2} \mathrm{H}_{4}$ is consumed, $\mathrm{C}_{2} \mathrm{H}_{3}$ is produced and oxidized through $\mathrm{R} 161$ to $\mathrm{HCO}$ and $\mathrm{CH}_{2} \mathrm{O}$. Subsequently, $\mathrm{CH}_{2} \mathrm{O}$ reacts with $\mathrm{OH}$ through the reaction,

$$
\mathrm{CH}_{2} \mathrm{O}+\mathrm{OH} \longrightarrow \mathrm{HCO}+\mathrm{H}_{2} \mathrm{O} \text {. }
$$

Thus, per $\mathrm{C}_{2} \mathrm{H}_{4}$ molecule consumed, two molecules of $\mathrm{HO}_{2}$ may form (Marinov et al. 1998).

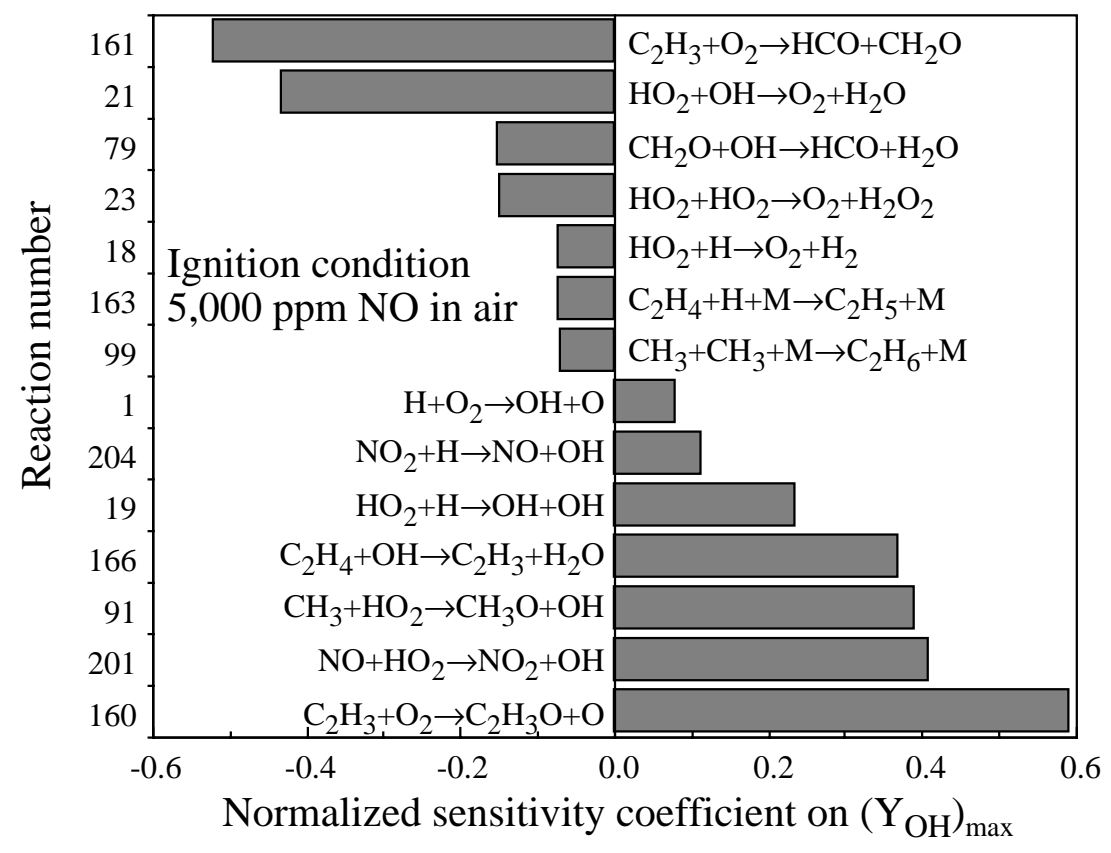

FIG. 6 Normalized sensitivity coefficients on $\left(Y_{\mathrm{OH}}\right)_{\max }$ at the ignition condition of $\mathrm{C}_{2} \mathrm{H}_{4} /$ air, with $5,000 \mathrm{ppm} \mathrm{NO}$ addition to the air stream $\left(T_{\text {air }}=1050 \mathrm{~K}, T_{\text {fuel }}=\right.$ $950 \mathrm{~K})$. 
Figure 6 depicts the normalized sensitivity coefficients of the most important reactions on the maximum mass fraction of $\mathrm{OH}$ radicals, $\left(Y_{\mathrm{OH}}\right)_{\max }$, at the ignition condition with 5,000 ppm NO addition to the air stream. The vertical axis denotes the reaction number as it appears in the mechanism. The effect of R160, R201, R91, R166, R19, and R204 on OH-production promotion can be seen to be large. As also shown earlier, the sensitivity to R201 is greater compared to R19. We also note that while R166 appears to be an $\mathrm{OH}$ sink, its net effect on overall $\mathrm{OH}$ production is large. It largely consumes $\mathrm{C}_{2} \mathrm{H}_{4}$, a process essential for the overall radical pool increase. Reactions R23, R161 and,

$\mathrm{R} 21$

R79

$$
\mathrm{HO}_{2}+\mathrm{OH} \longrightarrow \mathrm{O}_{2}+\mathrm{H}_{2} \mathrm{O}
$$

$$
\mathrm{CH}_{2} \mathrm{O}+\mathrm{OH} \longrightarrow \mathrm{HCO}+\mathrm{H}_{2} \mathrm{O}
$$

have a significant retarding effect on $\mathrm{OH}$ production. In $\mathrm{R} 21$ and $\mathrm{R} 79, \mathrm{HO}_{2}$ radicals are consumed and this is in competition with $\mathrm{R} 201$. OH radicals are also consumed in R21 and R79, and this is in competition with R166.

At the ignition point for the $50,000 \mathrm{ppm}$ case, $\mathrm{C}_{2} \mathrm{H}_{4}$ is consumed through reactions R166(29\%), R165(24\%), and

$\mathrm{R} 164(40 \%) \quad \mathrm{C}_{2} \mathrm{H}_{4}+\mathrm{H} \longrightarrow \mathrm{C}_{2} \mathrm{H}_{3}+\mathrm{H}_{2}$.

The role of $\mathrm{OH}$ in fuel consumption is reduced at this larger $\mathrm{NO}$ addition. However, it is still enhanced as compared to the pure $\mathrm{C}_{2} \mathrm{H}_{4}$ case. For large additions, NO is only partially consumed by R201(44\%), as additional consumption is caused through reaction,

$\mathrm{R} 289(38 \%) \quad \mathrm{NO}+\mathrm{HCCO} \longrightarrow \mathrm{HCNO}+\mathrm{CO}$

so that the effective OH-production sequence is not fully utilized. This inhibiting effect of R289, for large NO additions, was also reported by Nelson \& Haynes (1994). The reduced contribution of R201 in consuming NO is a result of the reduction of $\mathrm{HO}_{2}$ concentration. $\mathrm{HO}_{2}$ is readily produced through $\mathrm{O}_{2}$ reactions with the $\mathrm{HCO}$ and $\mathrm{C}_{2} \mathrm{H}_{5}$ radicals. Addition of large amounts of $\mathrm{NO}$ causes the $\mathrm{O}_{2}$ concentration in the oxidizer to be reduced. Thus, the rate of $\mathrm{HO}_{2}$ production is reduced. $\mathrm{HCCO}$ is largely produced from $\mathrm{CH}_{2} \mathrm{CO}$ reactions with $\mathrm{H}$ and $\mathrm{OH}$, while $\mathrm{CH}_{2} \mathrm{CO}$ is produced 
by R182-. HCNO entirely isomerizes to $\mathrm{HNCO}$ by reacting with $\mathrm{H}$, and $\mathrm{HNCO}$ is consumed through reaction,

$\mathrm{R} 280(80 \%) \quad \mathrm{HCNO}+\mathrm{H} \longrightarrow \mathrm{NH}_{2}+\mathrm{CO}$.

Through this alternative NO-consumption sequence, $\mathrm{NH}_{2}$ and $\mathrm{CO}$ are produced, that have no particular promoting effect on ignition. Thus, as NO is added in progressively larger amounts, the role of R289 is enhanced, over that of R201, and its promoting effect on ignition is reduced.

The effect of $\mathrm{NO}$ addition on $\sigma_{\text {ext }}$ was also assessed when $\mathrm{NO}$ is added to the air stream. The analysis showed that there are two competing mechanisms, namely OH-radical production through $\mathrm{R} 201$ and $\mathrm{O}_{2}$ concentration reduction as more $\mathrm{NO}$ is added. Extinction, being a high-temperature phenomenon, is particularly sensitive to the progress of the high activation energy, branching-reaction R1, whose rate is directly proportional to $\mathrm{O}_{2}$ concentration. The radical-producing mechanism initiated by R201 results in a moderate increase of $\sigma_{\text {ext }}$ for NO additions below $500 \mathrm{ppm}$. For larger amounts, the dilution effect of NO dominates, resulting, thus, in a noticeable reduction of $\sigma_{\text {ext }}$. The effect of $\mathrm{O}_{2}$-dilution is not as strong on ignition, which does not depend to the same extent on R1, as ignition is a lowertemperature, radical-deficient phenomenon.

The structure of the ignition and extinction points were also analyzed when NO is added on the fuel side. Cases of small and large NO additions were considered. For small amounts, with $\mathrm{NO}$ added to the fuel side, its effectiveness in producing $\mathrm{OH}$ radicals is reduced relatively to the addition on the air side. R201 is a key one in $\mathrm{OH}$ radical production and its rate is proportional to the molar concentrations of NO and $\mathrm{HO}_{2}$. Given that $\mathrm{HO}_{2}$ is largely produced in the oxygen-rich part of the domain, when NO is supplied to the fuel stream, the net rate of R201 is lower compared to when NO is added to the air stream. Figure 7 depicts results obtained from structure analysis for the ignition points corresponding to 5,000 ppm NO addition to the fuel and air streams. The spatial coordinate has been replaced by appropriate progress variables. Figure 7a shows the variation of the mass fraction of $\mathrm{HO}_{2}, Y_{\mathrm{HO}_{2}}$, with $Y_{\mathrm{NO}}$, the NO mass fraction. We find that when NO is added on the fuel side, the $Y_{\mathrm{HO}_{2}}$ maximum occurs in a regime of lower $Y_{\mathrm{NO}}$ values as compared to the case 

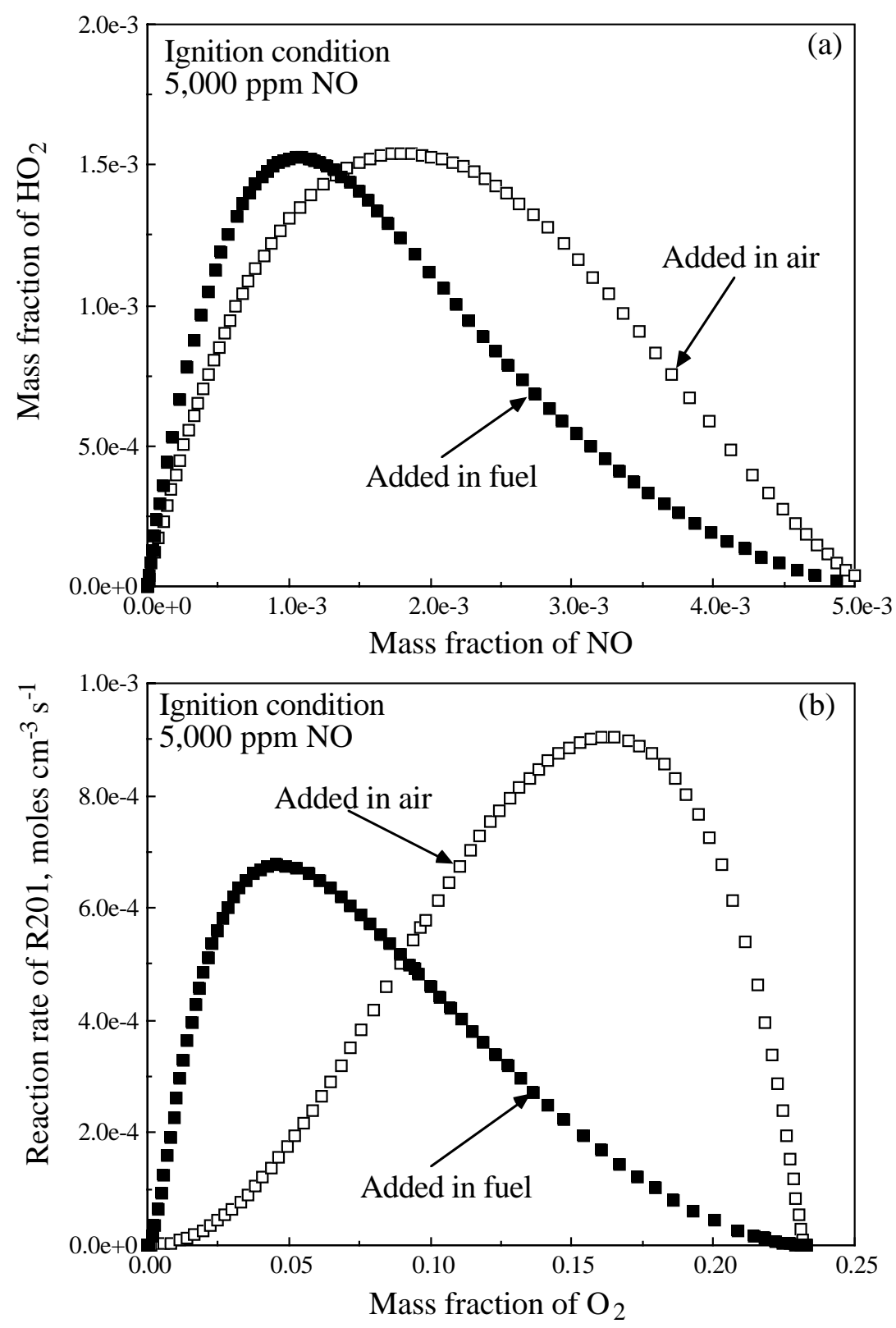

FIG. 7 Variation of (a) mass fraction of $\mathrm{HO}_{2}$ with mass fraction of $\mathrm{NO}$, and (b) R201 reaction rate with $\mathrm{O}_{2}$ mass fraction, at the ignition condition of $\mathrm{C}_{2} \mathrm{H}_{4}$ /air, with $5,000 \mathrm{ppm}$ NO addition $\left(T_{\text {air }}=1050 \mathrm{~K}, T_{\text {fuel }}=950 \mathrm{~K}\right)$.

of NO addition on the air side. Figure $7 \mathrm{~b}$ depicts the variation of the reaction rate of R201 with $Y_{\mathrm{O}_{2}}$, the $\mathrm{O}_{2}$ mass fraction. The maximum rate of $\mathrm{R} 201$ is lower and occurs at lower values of $Y_{\mathrm{O}_{2}}$, when $\mathrm{NO}$ is added on the fuel side, resulting, thus, in lower $\mathrm{OH}$-radical production. 
With increasing NO amounts on the fuel side, fuel dilution reduces the $\mathrm{HO}_{2}$ concentration, reducing the $\mathrm{OH}$ production rate through $\mathrm{R} 201$. However, this dilution effect is not as strong as in the case of $\mathrm{NO}$ addition on the air side. This is as expected, as the same ppm of added NO on the fuel side result in a lower fuel dilution, as compared to the corresponding dilution of $\mathrm{O}_{2}$ on the air side that already contains large amounts of $\mathrm{N}_{2}$. As a result, both $\sigma_{\text {ign }}$ and $\sigma_{\text {ext }}$ are minimally affected when NO is added on the fuel side at amounts ranging from 10,000 to 50,000 ppm.

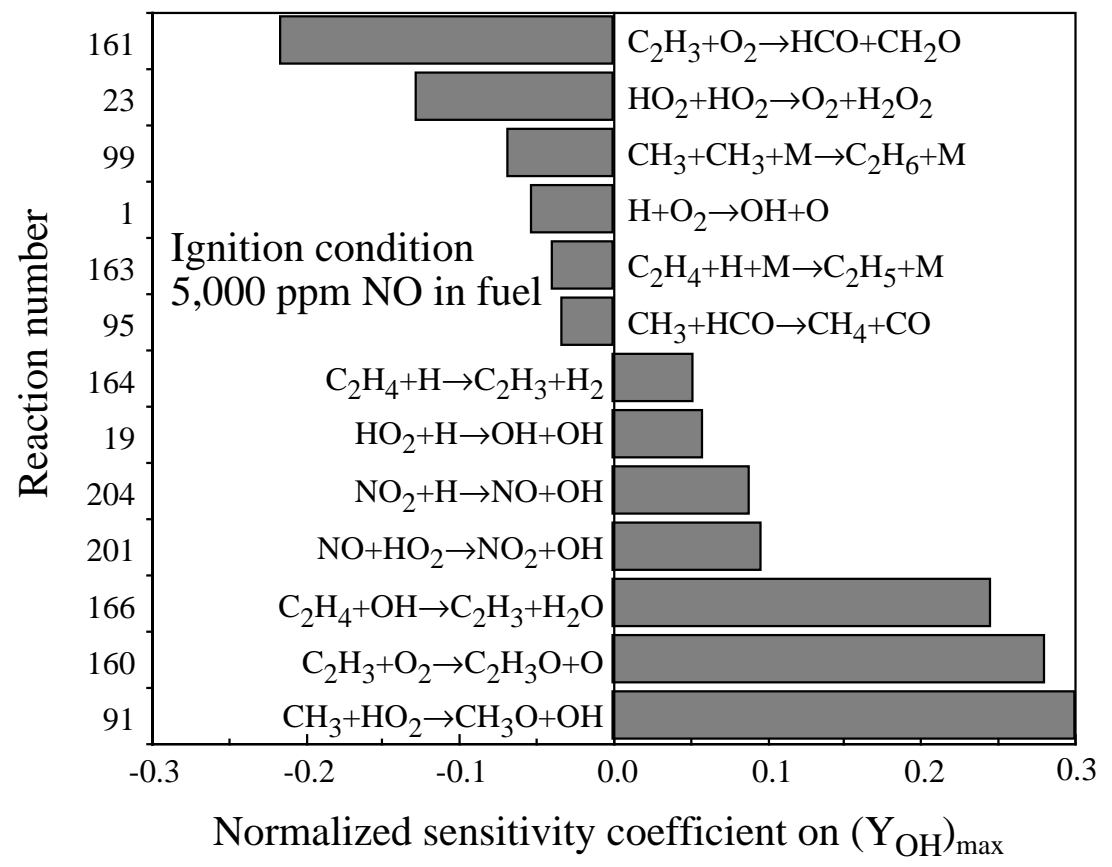

FIG. 8 Normalized sensitivity coefficients on $\left(Y_{\mathrm{OH}}\right)_{\max }$ at the ignition condition of $\mathrm{C}_{2} \mathrm{H}_{4} /$ air, with 5,000 ppm NO addition to fuel stream $\left(T_{\text {air }}=1050 \mathrm{~K}, T_{\text {fuel }}=950 \mathrm{~K}\right)$.

Figure 8 depicts the normalized sensitivity coefficients of the most important reactions on $\left(Y_{\mathrm{OH}}\right)_{\max }$, at the ignition condition for 5,000 ppm NO added to the fuel stream. The effect of R160, R201, R91, R166, R19, and R204 in promoting $\mathrm{OH}$ production remains large, but the overall sensitivities are lower compared to the ones shown in Fig. 6. Reactions R161 and R23 also have a retarding effect. We note, however, that while $\mathrm{R} 1$ promotes $\mathrm{OH}$ production at the conditions of Fig. 6 , it plays an inhibiting role at the conditions of Fig. 8. This is a result of the greater need of $\mathrm{O}_{2}$ for the formation of $\mathrm{HO}_{2}$, when $\mathrm{NO}$ is added to the fuel stream and the $\mathrm{R} 201$ rate is reduced, as shown in Fig. 7 . Thus, $\mathrm{O}_{2}$ consumption though $\mathrm{R} 1$, while 
it has some effect on $\mathrm{OH}$ production, reduces its reaction rate in $\mathrm{R} 160, \mathrm{R} 161$, and R50 that are essential for $\mathrm{HO}_{2}$ formation.

\section{$3.3 \quad F_{2}$ addition}

In ED98, $\mathrm{F}_{2}$ addition was found to promote ignition of blends anticipated from thermal cracking of jet fuels, as $\mathrm{F}$ radicals increase the consumption rate of hydrocarbons. The results of simulations with $1000 \mathrm{ppm}$ of $\mathrm{F}_{2}$ on the air side are shown in Fig. 9, along with those obtained for $\mathrm{C}_{2} \mathrm{H}_{4}$, and for $1000 \mathrm{ppm} \mathrm{NO}$ addition, also on the air side.

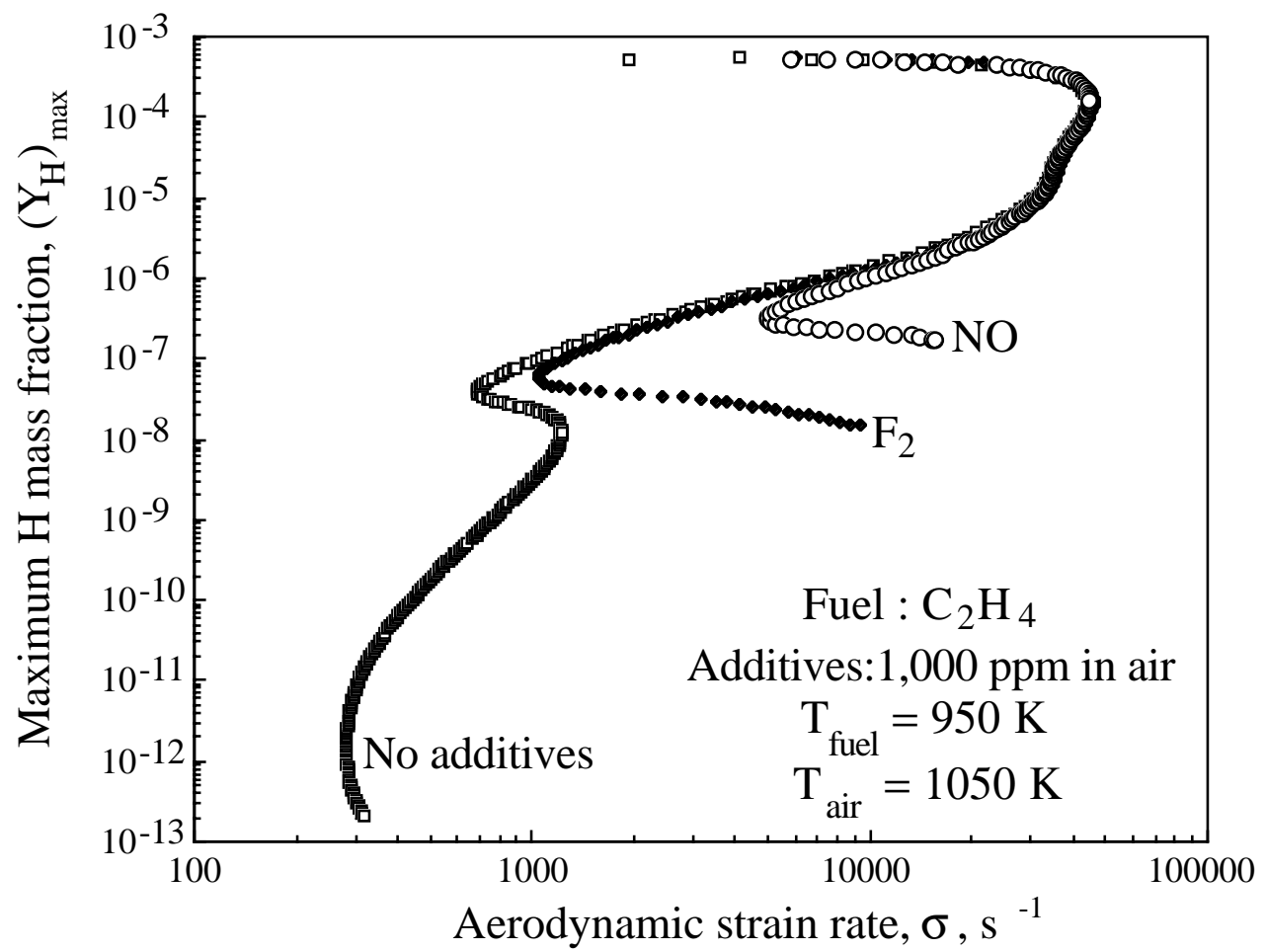

Fig. 9 Effect of $1000 \mathrm{ppm} \mathrm{F}_{2}$ or $\mathrm{NO}$ addition on S-curve response of $\mathrm{C}_{2} \mathrm{H}_{4}$ /air $\left(T_{\text {air }}=1050 \mathrm{~K}, T_{\text {fuel }}=950 \mathrm{~K}\right)$.

Addition of $1000 \mathrm{ppm}$ of $\mathrm{F}_{2}$ can be seen to promote $\mathrm{C}_{2} \mathrm{H}_{4}$ ignition, increasing $\sigma_{\text {ign }}$ by a factor of 3.5. However, it is less effective than addition of $1000 \mathrm{ppm}$ of $\mathrm{NO}$, which increases $\sigma_{\text {ign }}$ by a factor of 16.5. At the ignition point with $\mathrm{F}_{2}$ addition, fuel is consumed through R166(37\%), R165(30\%), R163(21\%), and
R301
$(7 \%)$
$\mathrm{C}_{2} \mathrm{H}_{4}+\mathrm{F} \longrightarrow \mathrm{C}_{2} \mathrm{H}_{3}+\mathrm{HF}$. 
Ignition is promoted both by the participation of R301 in the fuel consumption, as well as by the additional $\mathrm{OH}$-production mechanism that is active on the air side,

$$
\mathrm{H}_{2} \mathrm{O}+\mathrm{F} \longrightarrow \mathrm{OH}+\mathrm{HF}
$$

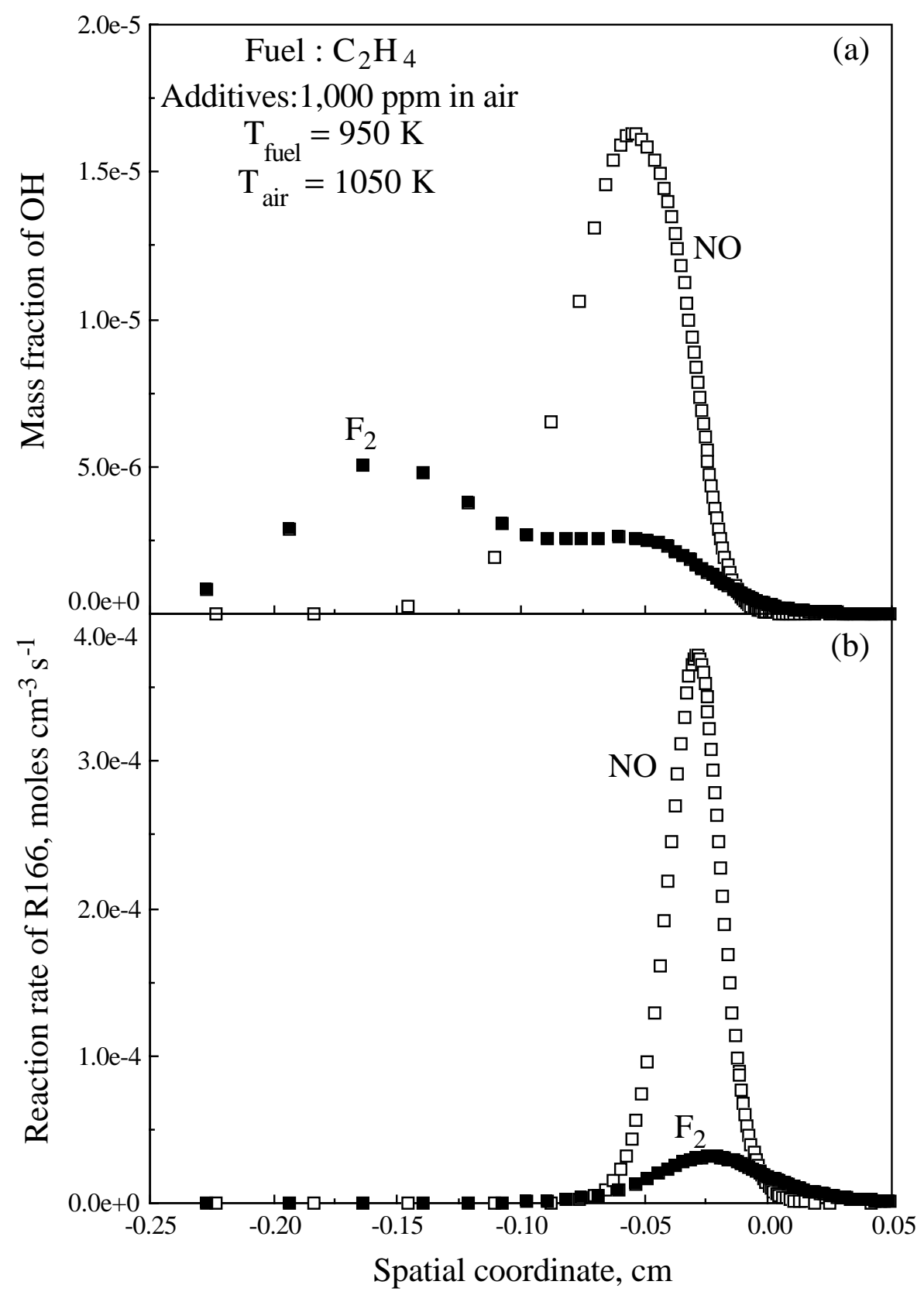

FIG. 10 Spatial variation of (a) mass fraction of $\mathrm{OH}$ and (b) rate of reaction R166 at the ignition condition of $\mathrm{C}_{2} \mathrm{H}_{4}$ /air, with independent additions of $1000 \mathrm{ppm}$ of $\mathrm{F}_{2}$ and $\mathrm{NO}$ in air $\left(T_{\text {air }}=1050 \mathrm{~K}, T_{\text {fuel }}=950 \mathrm{~K}\right)$. 
A comparison of the results of $\mathrm{F}_{2^{-}}$and $\mathrm{NO}$-addition reveals that the enhanced ignition promotion of $\mathrm{NO}$ as compared to $\mathrm{F}_{2}$ is caused by the higher $\mathrm{OH}$-production rate; a result of $\mathrm{R} 201$. OH mass fraction spatial variations at the ignition points, for $1000 \mathrm{ppm}$ additions of $\mathrm{F}_{2}$ and NO, are shown in Fig. 10a. The higher values for the NO addition can be noted. As a result, the R166 rate is substantially higher for NO addition, as shown in Fig. 10b, thus facilitating the ignition process. It is also interesting to note the peculiar spatial variation of the $\mathrm{OH}$ mass fraction for $\mathrm{F}_{2}$ addition. The initial increase of $\mathrm{OH}$ is largely caused by reaction R306 between F radicals and the $\mathrm{H}_{2} \mathrm{O}$ produced by $\mathrm{R} 166$. The plateau that is subsequently observed is caused by a competition between the consumption of $\mathrm{OH}$ through R166 and its production largely through R91.

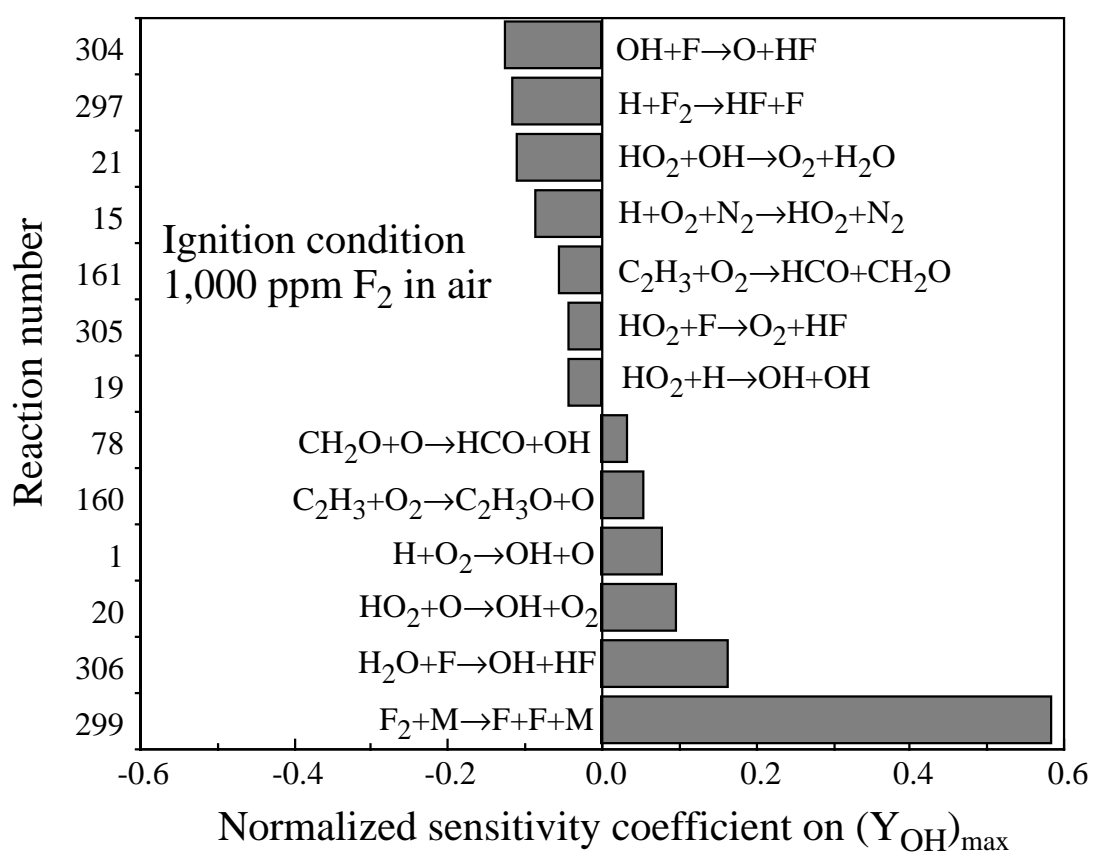

FIG. 11 Normalized sensitivity coefficients on $\left(Y_{\mathrm{OH}}\right)_{\max }$ at the ignition condition of $\mathrm{C}_{2} \mathrm{H}_{4} /$ air, with $1000 \mathrm{ppm} \mathrm{F}_{2}$ addition to the air stream $\left(T_{\text {air }}=1050 \mathrm{~K}, T_{\text {fuel }}=\right.$ $950 \mathrm{~K})$.

Figure 11 depicts the normalized sensitivity coefficients of the most important reactions on $\left(Y_{\mathrm{OH}}\right)_{\max }$, at the ignition condition with $1000 \mathrm{ppm} \mathrm{F}_{2}$ added to the air stream. Reactions R1, R306, and

$$
\mathrm{F}_{2}+\mathrm{M} \longrightarrow \mathrm{F}+\mathrm{F}+\mathrm{M} \text {, }
$$


R20

$$
\mathrm{HO}_{2}+\mathrm{O} \longrightarrow \mathrm{OH}+\mathrm{O}_{2}
$$

promote $\mathrm{OH}$ production, as $\mathrm{R} 299$ is a rate-limiting reaction resulting in $\mathrm{F}$, and $\mathrm{R} 1$, R306, and R20 directly produce $\mathrm{OH}$. Reactions R21 and

R304

$$
\mathrm{OH}+\mathrm{F} \longrightarrow \mathrm{O}+\mathrm{HF}
$$

R297

$$
\mathrm{H}+\mathrm{F}_{2} \longrightarrow \mathrm{HF}+\mathrm{F} \text {, }
$$

$\mathrm{R} 15$

$$
\mathrm{H}+\mathrm{O}_{2}+\mathrm{N}_{2} \longrightarrow \mathrm{HO}_{2}+\mathrm{N}_{2}
$$

inhibit $\mathrm{OH}$ production. R21 results in stable products, R304 consumes OH radicals as well as F radicals needed by R306, and R297 and R15 consume H radicals needed by $\mathrm{R} 1$.

\subsection{Simultaneous NO and $\mathrm{F}_{2}$ addition}

The simultaneous presence of $\mathrm{NO}$ and $\mathrm{F}_{2}$ in a reacting flow can result in enhanced radical production through the low activation energy reaction,

$$
\mathrm{NO}+\mathrm{F}_{2} \longrightarrow \mathrm{FNO}+\mathrm{F} \text {. }
$$

R295 is a hypergolic reaction that can proceed at high rates even at low temperatures (e.g., Mungal \& Dimotakis 1984, Dimotakis \& Hall 1987). The F radicals produced can facilitate the consumption of the fuel, as described earlier. In ED98, it was found that a simultaneous addition of $10,000 \mathrm{ppm}$ of $\mathrm{NO}$ on the fuel-blend side and $10,000 \mathrm{ppm}$ of $\mathrm{F}_{2}$ on the air side resulted in an increase of $\sigma_{\text {ign }}$ by a factor of about 8 , to a value of approximately $4000 / \mathrm{s}$. The fuel blend in those simulations was largely comprised of $\mathrm{CH}_{4}$ and $\mathrm{C}_{2} \mathrm{H}_{4}$ in addition to smaller amounts of $\mathrm{C}_{2} \mathrm{H}_{2}$ and $\mathrm{H}_{2}$.

Simulations were conducted by adding various amounts of $\mathrm{NO}$ on the $\mathrm{C}_{2} \mathrm{H}_{4}$ side and $\mathrm{F}_{2}$ on the air side. The results are shown in Fig. 12. The ignition promotion of $\mathrm{C}_{2} \mathrm{H}_{4}$ is apparent. An equal addition of 10,000 ppm of $\mathrm{NO}$ and $\mathrm{F}_{2}$, for example, results in $\sigma_{\text {ign }}=42,000 / \mathrm{s}$, an increase by a factor of 140 over the $\sigma_{\text {ign }}$ of pure $\mathrm{C}_{2} \mathrm{H}_{4}$. Recall, that in the absence of $\mathrm{F}_{2}, 10,000 \mathrm{ppm}$ of $\mathrm{NO}$ added on the fuel 


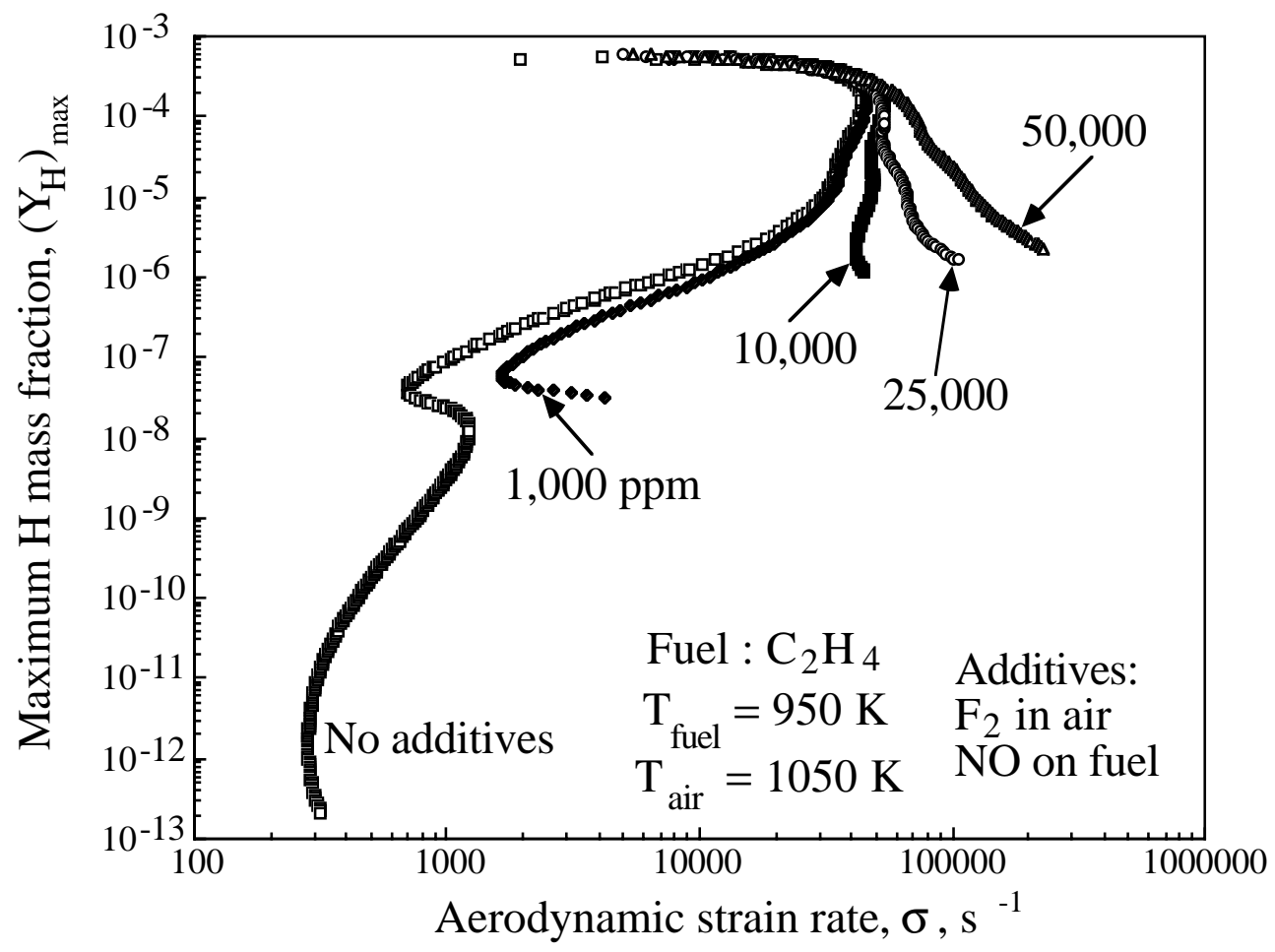

FIG.12 Effect of simultaneous addition of $\mathrm{F}_{2}$ to air and NO to fuel streams on S-curve response of $\mathrm{C}_{2} \mathrm{H}_{4} /$ air $\left(T_{\text {air }}=1050 \mathrm{~K}, T_{\text {fuel }}=950 \mathrm{~K}\right)$.

side results in $\sigma_{\text {ign }}=27,000 / \mathrm{s}$, indicating the synergistic effect of $\mathrm{F}_{2}$ and $\mathrm{NO}$ on ignition. The results in Fig. 12 indicate that for additions above 25,000 ppm, the $\left(\mathrm{C}_{2} \mathrm{H}_{4}+\mathrm{NO}\right) /\left(\right.$ air $\left.+\mathrm{F}_{2}\right)$ system becomes hypergolic, with distinct ignition and extinction conditions that can be identified. Instead, there is a monotonic reduction of the radical concentration as strain rate increases.

Ignition analysis with $10,000 \mathrm{ppm}$ addition reveals that $\mathrm{C}_{2} \mathrm{H}_{4}$ is consumed through R166(40\%), R165(28\%), R163(16\%), and R301(9\%), with NO consumed through R201(85\%) and R295(11\%), and $\mathrm{F}_{2}$ consumption through R295(14\%) and $\mathrm{R} 297$ (81\%)

$$
\mathrm{H}+\mathrm{F}_{2} \longrightarrow \mathrm{HF}+\mathrm{F}
$$

The simultaneous presence of $\mathrm{NO}$ and $\mathrm{F}_{2}$ promotes $\mathrm{C}_{2} \mathrm{H}_{4}$ ignition more effectively than NO alone, with $\mathrm{F}$ radicals facilitating $\mathrm{C}_{2} \mathrm{H}_{4}$ consumption through $\mathrm{R} 301$. Subsequent reactions of $\mathrm{C}_{2} \mathrm{H}_{3}$ produce $\mathrm{OH}$, as described above. $\mathrm{OH}$ is, of course, very important in enhancing the main fuel-consuming R166. 
The combined effect of $\mathrm{F}_{2}$ and $\mathrm{NO}$ on the fuel consumption process is more profound for larger additions. For example, analysis of a highly-strained condition with $25,000 \mathrm{ppm}$ addition revealed that $21 \%$ of the fuel is consumed by R301, compared to $9 \%$ for $10,000 \mathrm{ppm}$ addition. Furthermore, the contribution of R295 in NO consumption increases to $32 \%$, from $11 \%$ for 10,000 ppm addition. Similarly, $43 \%$ of $\mathrm{F}_{2}$ is consumed by $\mathrm{R} 295$. Under such conditions, the overall system became hypergolic, as a result of the hypergolic nature of R295.

The results in Fig. 12 also demonstrate that simultaneous additions of $\mathrm{F}_{2}$ and NO increase $\sigma_{\text {ext }}$. This additional resistance to extinction is a result of the enhanced $\mathrm{OH}$ production through R306. At the extinction condition, F radicals are produced by R295 and R297.

\section{5 $\quad \mathrm{H}_{2}$ addition}

The effect of $\mathrm{H}_{2}$ addition on $\mathrm{C}_{2} \mathrm{H}_{4}$ ignition was also studied. The simulations include the addition of $1000 \mathrm{ppm}$ on the fuel side only, to preserve the non-premixed nature of the system. The results are shown in Fig. 13, along with those for pure $\mathrm{C}_{2} \mathrm{H}_{4}$, and $1000 \mathrm{ppm} \mathrm{NO}$ addition to the fuel stream. Although $\mathrm{H}_{2}$ is an excellent ignition promoter, it is interesting to note the relatively minor increase in $\sigma_{\text {ign }}$, compared to an addition of a similar amount of NO. The small ignition promotion is caused by the additional $\mathrm{H}$ radicals produced as a result of $\mathrm{H}_{2}$ consumption. By

comparison, $1000 \mathrm{ppm}$ of $\mathrm{NO}$ on the fuel stream results in an increase of $\sigma_{\text {ign }}$ by a factor of about 4 . 


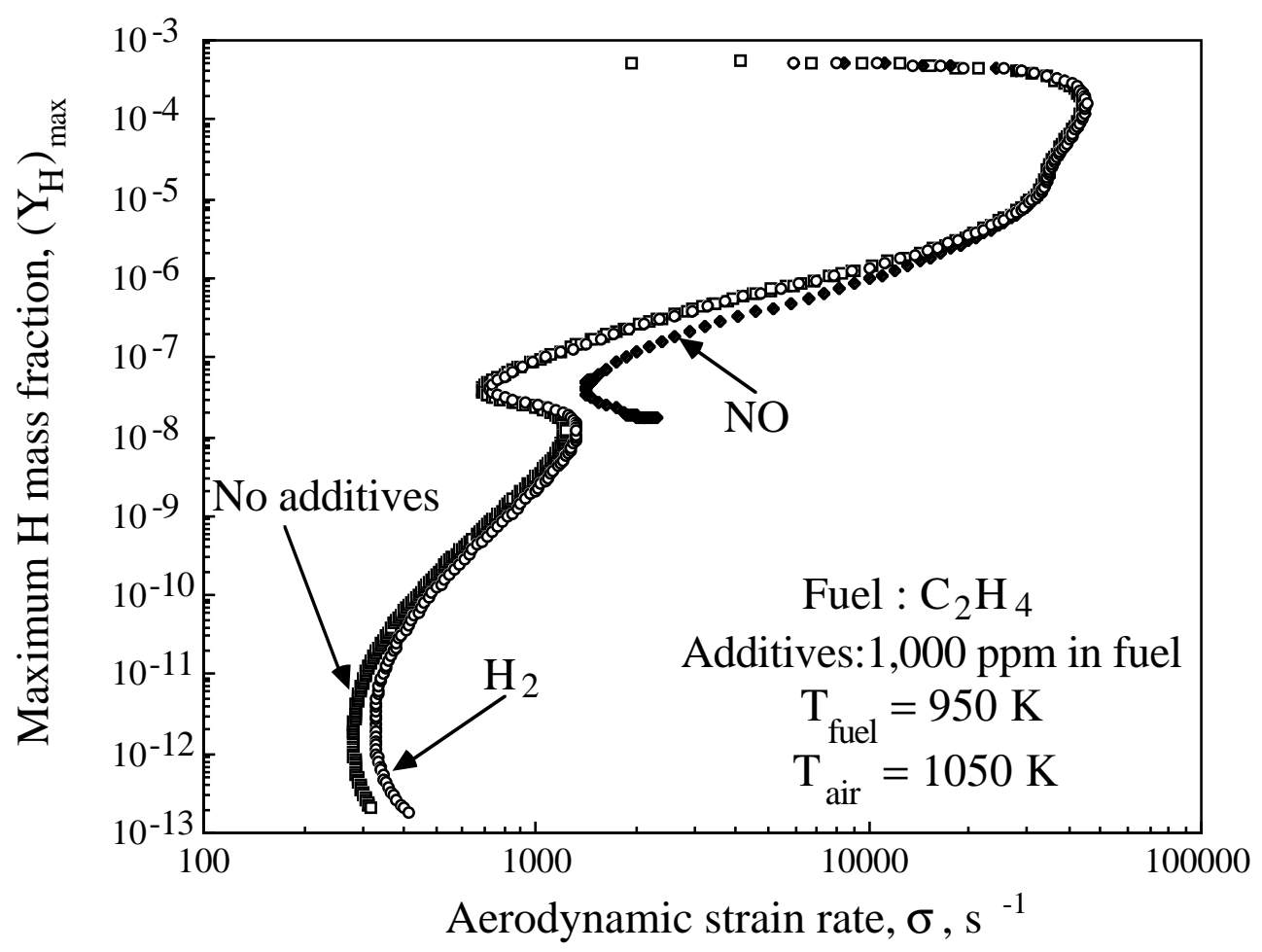

Fig. 13 Influence of $1000 \mathrm{ppm}$ addition of $\mathrm{H}_{2}$ to fuel stream on S-curve response of $\mathrm{C}_{2} \mathrm{H}_{4} /$ air $\left(T_{\text {air }}=1050 \mathrm{~K}, T_{\text {fuel }}=950 \mathrm{~K}\right)$. Comparison with pure $\mathrm{C}_{2} \mathrm{H}_{4}$ fuel stream and $1000 \mathrm{ppm}$ NO addition to fuel stream.

\section{Concluding remarks}

The effects of $\mathrm{NO}, \mathrm{F}_{2}$, and $\mathrm{H}_{2}$ as additives on non-premixed ignition of heated $\mathrm{C}_{2} \mathrm{H}_{4}$ counterflowing against heated air were numerically investigated for conditions relevant to SCRAMJET's. The simulations were conducted along the stagnation streamline of an opposed-jet configuration with detailed descriptions of molecular transport and chemical kinetics. A two-point continuation approach was implemented, permitting the entire S-curve response to strain rate to be simulated. Simulations were conducted at atmospheric pressure, for free-stream reactant temperatures of $T_{\text {air }}=1050 \mathrm{~K}$ and $T_{\text {fuel }}=950 \mathrm{~K}$.

The study reveals that the addition of NO can result in a substantial increase in ignition strain rate, $\sigma_{\text {ign }}$, by a factor as high as 120 . This substantial ignition promotion is caused by a radical-production mechanism resulting from the interaction between $\mathrm{NO}$ and $\mathrm{HO}_{2}$, the latter being effectively produced during $\mathrm{C}_{2} \mathrm{H}_{4}$ 
oxidation. Ignition was found to be very sensitive to small amounts of NO addition, reaching a maximum $\sigma_{\text {ign }}$ at about $10,000 \mathrm{ppm}(1 \%)$. Higher amounts of NO, up to $50,000 \mathrm{ppm}$, result in lower $\sigma_{\text {ign }}$ when $\mathrm{NO}$ is added to the air stream, while a nearly-constant value is reached with NO in the fuel stream. For amounts less than $10,000 \mathrm{ppm}$, NO addition to the air stream is more effective in promoting ignition.

Ignition of $\mathrm{C}_{2} \mathrm{H}_{4}$ with addition of small amounts of $\mathrm{F}_{2}$ and/or $\mathrm{H}_{2}$ was also investigated. Although ignition is promoted, the increase in $\sigma_{\text {ign }}$ is substantially less compared to that from $\mathrm{NO}$ addition. However, the simultaneous addition of $\mathrm{F}_{2}$ on the air side and NO on the fuel side further promotes ignition, relative to NO alone, and for additions of about 25,000 ppm, the system becomes hypergolic.

This investigation indicates that ignition can be achieved for strain rates of the order of $32,000 / \mathrm{s}$ by using $\mathrm{C}_{2} \mathrm{H}_{4}$ and $\mathrm{NO} . \mathrm{C}_{2} \mathrm{H}_{4}$ can be either supplemented or derived from the products of endothermic fuel cracking. Similarly, the small amounts of NO can be added to the air stream. Simultaneous addition of amounts $\mathrm{F}_{2}$ and $\mathrm{NO}$ at a level of $25,000 \mathrm{ppm}$ in $\mathrm{C}_{2} \mathrm{H}_{4}$, can result in ignition under any strain rate. Such additions would only be required for a brief portion of the SCRAMJET flight profile, corresponding the the lower Mach number regime.

In closing, we recall that the present results are based on the Wang \& Frenklach (1997) reaction mechanism that satisfactorily accounts for known $\mathrm{C}_{2} \mathrm{H}_{4}$ flame behavior. However, there is no clear consensus regarding the oxidation steps controlling $\mathrm{C}_{2} \mathrm{H}_{4}$ ignition at this time. As discussed above, a major role in the ignition process is played by the vinyoxy radical $\left(\mathrm{CH}_{2} \mathrm{CHO}\right)$ whose kinetics are not wellestablished (Wang \& Frenklach 1997; Marinov et al. 1998; H. Wang 1999, personal communication). There are no flame-ignition/-extinction data available at present, especially for SCRAMJET temperatures, to test such mechanisms in this important regime and we recognize the need to validate the kinetics and our results, which we hope point in the direction of some ignition-enhancement possibilities. 


\section{Acknowledgments}

This study was funded by the Air Force Office of Scientific Research, AirBreathing Propulsion Program, under Grant F49620-98-1-0052, whose support is gratefully acknowledged.

\section{References}

Bowman, C. T., Frenklach, M., Gardiner, W. \& Smith, G. 1995 The GRI 2.1 Mechanism. pvte. communication.

Bromly, J. H., Barnes, F. J., Mandyczewsky, R., Edwards, T. J. \& HAYnes, B. S. 1992 An Experimental Investigation of the Mutually Sensitized Oxidation of Nitric Oxide and n-Butane. Twenty-Fourth Symposium (International) on Combustion The Combustion Institute, Pittsburgh, 899-907.

Burgess, D. R. F., Zachariah, M. R., Jr., Tsang, W. \& Westmoreland, P. R. 1997 Thermochemical and Chemical Kinetic Data for Fluorinated Hydrocarbons. NIST Report.

Dimotakis, P. E. \& Hall, J. L. 1987 A simple model for finite chemical kinetics analysis of supersonic turbulent shear layer combustion. AIAA/SAE/ASME/ASEE $23^{\text {rd }}$ Joint Propulsion Meeting, Paper 87-1879.

Doughty, A., Barnes, F. J., Bromly, J. H. \& Haynes, B. S. 1996 The Mutually Sensitized Oxidation of Ethylene and NO: An Experimental and Kinetic Modeling Study. Twenty-Sixth Symposium (International) on Combustion. The Combustion Institute, Pittsburgh, 589-596.

EDWARDs, T. 1996 Fuels and Fuel System Area: Air Force Perspective. AFOSR/NASA Workshop on Supersonic Scramjet Combustion. 13-16 May 1996, Newport News, VA.

Egolfopoulos, F. N. 1994a Dynamics and Structure of Unsteady, Strained, Laminar Premixed Flames. Twenty-Fifth Symposium (International) on Combustion The Combustion Institute, Pittsburgh, 1365-1373. 
Egolfopoulos, F. N. 1994b Geometric and Radiation Effects on Steady and Unsteady Strained Laminar Flames. Twenty-Fifth Symposium (International) on Combustion The Combustion Institute, Pittsburgh, 1375-1381.

Egolfopoulos, F. N. \& CAmpbell, C. S. 1996 Unsteady, counterflowing, strained diffusion flames: frequency response and scaling. J. Fluid Mech. 318, $1-29$.

Egolfopoulos, F. N. \& Dimotakis, P. E. 1998 Non-premixed hydrocarbon ignition at high strain rates. Twenty-Seventh Symposium (International) on Combustion. The Combustion Institute, Pittsburgh, 641-648.

Egolfopoulos, F. N., Dimotakis, P. E. \& Bond, C. L. 1996 On Strained Flames with Hypergolic Reactants: The $\mathrm{H}_{2} / \mathrm{NO} / \mathrm{F}_{2}$ System in High-Speed, Supersonic and Subsonic Mixing-Layer Combustion. Twenty-Sixth Symposium (International) on Combustion. The Combustion Institute, Pittsburgh, 2885-2893.

Egolfopoulos, F. N., Zhang, H. \& Zhang, Z. 1997 Wall Effects on the Propagation and Extinction of Strained, Laminar, Premixed Flames. Comb. and Flame 109, 237-252.

Fotache, C. G., Kreutz, T. G. \& Law, C. K. 1997a Ignition of Counterflowing Methane versus Heated Air under Reduced and Elevated Pressures. Comb. and Flame 108, 442-470.

Fotache, C. G., Kreutz, T. G. \& Law, C. K. 1997b Ignition of HydrogenEnriched Methane versus Heated Air. Comb. and Flame 110, 429-440.

KEE, R. J. 1990 Opposed jet, premixed-flame solver. pvte. communication.

Kee, R. J., Grcar, J. F., Smooke, M. D. \& Miller, J. A. 1985 A Fortran program for modeling steady laminar one-dimensional premixed flames. SAND858240 DoE report.

Kee, R. J., Rupley, F. M. \& Miller J. A. 1989 Chemkin-II: A Fortran Chemical Kinetics Package for the Analysis of Gas-Phase Chemical Kinetics. Sandia Report SAND89-8009.

Kee, R. J., Warnatz, J. \& Miller, J. A. 1983 A FORTRAN Computer Code Package for the Evaluation of Gas-Phase Viscosities, Conductivities and Diffusion Coefficients. Sandia Report SAND83-8209. 
Kreutz, T. G. \& LaW, C. K. 1996 Ignition in nonpremixed counterflowing hydrogen versus heated air: Computational study with detailed chemistry. Comb. and Flame 104, 157-175.

LAW, C. K. 1998 Chemical Kinetics and Aerodynamics of Ignition. Abstracts, ARO and AFOSR Contractors' Meeting in Chemical Propulsion (29 June - 1 July, Long Beach, CA).

Marinov, N., Pitz, W., Westbrook, C., Hori, M. \& Matsunaga, N. 1998 An Experimental and Kinetic Calculation of the Promotion Effect of Hydrocarbons on the NO- $\mathrm{NO}_{2}$ Conversion in a Flow Reactor. Twenty-Seventh Symposium (International) on Combustion. The Combustion Institute, Pittsburgh, 389-396.

Mungal, M. G. \& Dimotakis, P. E. 1984 Mixing and combustion with low heat release in a turbulent mixing layer. J. Fluid Mech. 148, 349-382.

Nelson, P. F. \& Haynes, B. S. 1994 Hydrocarbon-NOx Interactions at Low Temperatures - 1 . Conversion of $\mathrm{NO}$ to $\mathrm{NO}_{2}$ Promoted by Propane and the Formation of HNCO. Twenty-Fifth Symposium (International) on Combustion The Combustion Institute, Pittsburgh, 1003-1010.

Nishioka, M., Law, C. K. \& Takeno, T. 1996 A Flame-Controlling Continuation Method for Generating S-Curve Responses with Detailed Chemistry. Comb. and Flame 104, 328-342.

Tan, Y., Fotache, C. G. \& Law, C. K. 1999 Effects of NO on the Ignition of Hydrogen and Hydrocarbons by Heated Counterflowing Air. Comb. and Flame (in press).

Wang, H. \& Frenklach, M. 1997 A Detailed Kinetic Modeling Study of Aromatics Formation in Laminar Premixed Acetylene and Ethylene Flames. Comb. and Flame 110, 173-221.

Westmoreland, P. R. 1997 pvte. communication.

Williams, F. A. 1985 Combustion Theory. The Fundamental Theory of Chemically Reacting Flow Systems. $2^{\text {nd }}$ edition, Benjamin/Cummings, Menlo Park, CA. 